\title{
Morphometric analysis of fossil bumble bees (Hymenoptera, Apidae, Bombini) reveals their taxonomic affinities
}

\author{
Manuel Dehon', Michael S. Engel 2,3, Maxence Gérard', A. Murat Aytekin ${ }^{1,4}$, \\ Guillaume Ghisbain', Paul H. Williams ${ }^{5}$, Pierre Rasmont ${ }^{1}$, Denis Michez'
}

I Laboratory of Zoology, Research Institute of Biosciences, University of Mons, Place du parc 20, 7000 Mons, Belgium 2 Division of Invertebrate Zoology, American Museum of Natural History, Central Park West at 79't, New York, NY 10024-5192, USA 3 Division of Entomology, Natural History Museum, and Department of Ecology and Evolutionary Biology, University of Kansas, 1501 Crestline Drive - Suite 140, Lawrence, KS 66045, USA 4 Pamukkale Sitesi, B Blok, Çayyolu, Ankara, Turkey 5 Department of Life Sciences, Natural History Museum, Cromwell Road, London SW7 5BD, UK

Corresponding author: Denis Michez (denis.michez@umons.ac.be)

Academic editor: M. Ohl | Received 30 November 2018 | Accepted 28 September 2019 | Published 21 November 2019

http://zoobank.org/8C9F49DC-20A7-46B1-B864-B41869F1A2F3

Citation: Dehon M, Engel MS, Gérard M, Aytekin AM, Ghisbain G, Williams PH, Rasmont P, Michez D (2019) Morphometric analysis of fossil bumble bees (Hymenoptera, Apidae, Bombini) reveals their taxonomic affinities. ZooKeys 891: 71-118. https://doi.org/10.3897/zookeys.891.32056

\begin{abstract}
Bumble bees (Bombus spp.) are a widespread corbiculate lineage (Apinae: Corbiculata: Bombini), mostly found among temperate and alpine ecosystems. Approximately 260 species have been recognized and grouped recently into a simplified system of 15 subgenera. Most of the species are nest-building and primitively eusocial. Species of Bombus have been more intensely studied than any other lineages of bees with the exception of the honey bees. However, most bumble bee fossils are poorly described and documented, making their placement relative to other Bombus uncertain. A large portion of the known and presumed bumble bee fossils were re-examined in an attempt to better understand their affinities with extant Bombini. The taxonomic affinities of fossil specimens were re-assessed based on morphological features and previous descriptions, and for 13 specimens based on geometric morphometrics of forewing shape. None of the specimens coming from Eocene and Oligocene deposits were assigned within the contemporary shape space of any subgenus of Bombus. It is shown that Calyptapis florissantensis Cockerell, 1906 (EoceneOligocene boundary, Florissant shale, Colorado, USA) and Oligobombus cuspidatus Antropov, 2014 (Late Eocene, Bembridge Marls) likely belong to stem-group Bombini. Bombus anacolus Zhang, 1994, B. dilectus
\end{abstract}

Copyright Manuel Dehon et al. This is an open access article distributed under the terms of the Creative Commons Attribution License (CC BY 4.0), which permits unrestricted use, distribution, and reproduction in any medium, provided the original author and source are credited. 
Zhang, 1994, B. luianus Zhang, 1990 (Middle Miocene, Shanwang Formation), as well as B. vetustus Rasnitsyn \& Michener, 1991 (Miocene, Botchi Formation) are considered as species inquirenda. In the Miocene, affinities of fossils with derived subgenera of Bombus s. l. increased, and some are included in the shape space of contemporary subgenera: Cullumanobombus (i.e., B. pristinus Unger, 1867, B. randeckensis Wappler \& Engel, 2012, and B. trophonius Prokop, Dehon, Michez \& Engel, 2017), Melanobombus (i.e., B. cerdanyensis Dehon, De Meulemeester \& Engel, 2014), and Mendacibombus (i.e., B. beskonakensis (Nel $\&$ Petrulevičius, 2003), new combination), agreeing with previous estimates of diversification.

\section{Keywords}

Bombus, evolution, fossil, geometric morphometrics, review, taxonomy

\section{Introduction}

Bumble bees (Bombini: Bombus Latreille, 1802) are a lineage of corbiculate bees (Apidae: Apinae) dominant in many temperate and alpine ecosystems (Williams 1998; Michener 2007). Like almost all bees, they feed entirely on pollen for protein and lipid resources, and nectar for carbohydrates. Bombus are valuable for agricultural pollination (e.g., Pouvreau 1984; Plowright and Laverty 1987), and have been domesticated since the 1970s (Röseler 1973), resulting in commercial rearing with probably several millions of colonies produced per year (Velthuis and Doorn 2006; Goulson 2010). Approximately 260 species have been recognized (Williams 1998) and grouped into a simplified system of 15 subgenera (Williams et al. 2008). Most of the species are nest-building (i.e., females collect pollen using a corbicula) and primitively eusocial, meaning that the life cycle includes a solitary queen stage (Heinrich 1979). However, several species are social parasites: all species of the subgenus Psithyrus Lepeletier, 1832, and the species Bombus (Thoracobombus) inexspectatus (Tkalců, 1963), B. (Alpinobombus) hyperboreus Schoenherr, 1809, and B. (Alpinobombus) natvigi Richards 1931 (Hines and Cameron 2010; Brasero et al. 2018; Williams et al. 2019). Morphologically, the genus Bombus is characterized by an intermediate to very large body size (9-22 $\mathrm{mm}$ long), often with conspicuous color patterns (Williams 2007), the presence of outer mandibular grooves, an apically closed forewing marginal cell, the presence of an auricle at the metatibiametabasitarsus junction, the presence of a supra-alar carina, the hamuli not reduced on the hind wing margin, the absence of a jugal lobe, and glabrous compound eyes (Engel 2001; Michener 1990, 2007; Engel and Rasmussen in press). In females, the pretarsal claws are cleft, with a small arolia present, and the metatibial spurs are present (Engel 2001; Michener 1990, 2007; Engel and Rasmussen in press). Both wings have strong and complete venation (Michener 1990, 2007). In the forewing, the marginal cell is longer than the distance from its apex to the forewing tip; the pterostigma is small, scarcely longer than the prestigma; r-rs arises near or beyond the middle of the pterostigma; and the margin within the marginal cell is straight or commonly concave. Bombus s. l. display interspecific diversity in structures like male genitalia, female sting, color pattern, and mandibular shape (Engel 2001; Michener 1990, 2007). 
Bumble bees have been more intensely studied than other lineages of bees with the exception of the honey bees (Apini: Apis L., 1758) (Michener 2007). Those studies include taxonomic and cladistic investigations, many of them focusing on the recovery of a robust hypothesis of phylogenetic relationships among and within the subgenera (e.g., Vogt 1911; Milliron 1961, 1973a, b; Tkalců 1972; Pekkarinen 1979; Pekkarinen et al. 1979; Obrecht and Scholl 1981; Ito 1985; Williams 1985; Pamilo et al. 1987; Cameron et al. 2007). Bumble bees exhibit higher species diversity in cooler climates of the Holarctic region, with more species and subgenera in Eurasia than in North America (Williams 1998). Historical patterns of dispersal among the continents and climatic associations of bumble bee origins were described by Skorikov (1923), Williams (1985), Kawakita et al. (2004), and Williams et al. (2018). Hines (2008) recently estimated divergence times using fossil calibrations and molecular rates derived from the literature. However, she purposefully excluded fossils of Bombus s. l. for her analyses, and instead considered that reliable bumble bee fossils were too poorly preserved to reveal good morphological synapomorphies for placement within Bombus s. 1. Hines (2008) therefore decided to use outgroup fossils and subfossils as calibration points [i.e., the subfossil stingless bees Liotrigona vetula Moure \& Camargo, 1978, Hypotrigona gribodoi (Magretti, 1884), and fossil meliponines Liotrigonopsis rozeni Engel, 2001, Kelneriapis eocenica (Kelner-Pillault, 1969), and Proplebeia dominicana (Wille \& Chandler, 1964)]. Those analyses estimated that the crown group of extant Bombus s. 1. originated in the Upper Eocene to Middle Oligocene, i.e., 40.0-25.0 Ma, perhaps near the Eocene-Oligocene boundary (i.e., 34.0 Ma). It is unclear whether the purposeful exclusion of Cretotrigona prisca (Michener \& Grimaldi, 1988), from $70 \mathrm{Ma}$, as an outgroup calibration point impacted the overall estimated divergence times obtained by Hines (2008). Regardless, the Eocene-Oligocene transition is a well-documented global cooling period that resulted in significant extinctions, particularly across the Northern Hemisphere (Zachos et al. 2008; Hansen et al. 2013). An Old World ancestor of extant Bombus s. 1. was supported, with early dispersal events from the Old World into the New World and North America to South America (Williams 1985; Hines 2008). In the phylogenetic tree presented in Cameron et al. (2007) and Hines (2008), Mendacibombus is sister to all other clades, while extant species of this subgenus are estimated to have diverged in the last $10 \mathrm{Ma}$ (Williams et al. 2016). A global revision of available bumble bee fossils is needed to corroborate or reject temporal hypotheses proposed by Hines (2008), and more critically the discovery of more and better-preserved fossil bombines is needed as the record of this interesting tribe is quite scant.

Bombus is the only contemporary genus of the tribe Bombini but additional fossils have been associated with this tribe, and these have either been proposed within the genus, or in putatively extinct genera. Overall, the fossil record of bees is comparatively scarce, with only around 200 described species (e.g., Kotthoff et al. 2011; Michez et al. 2012; Wappler et al. 2012; Engel and Michener 2013a; Engel and Breitkreuz 2013; Engel et al. 2013, 2014, 2018; Dewulf et al. 2014; Dehon et al. 2014, 2017; Engel 2014, 2019a, b; Prokop et al. 2017). In total, 14 bombine fossil species have been described, 
each described from a single specimen with the exception of Calyptapis florissantensis Cockerell which was documented from two specimens (Table 1). Most of these are poorly described and documented, making their placement relative to extant Bombus uncertain. The majority of the specimens were found in Miocene sediments and have been described in the genera Bombus Latreille, 1802, Oligoapis Nel \& Petrulevičius, 2003, Oligobombus Antropov, 2014, Paraelectrobombus Nel \& Petrulevičius, 2003, and Calyptapis Cockerell, 1906 (Table 1). The aim of the present study is to provide a taxonomic overview of the available fossil bumble bees and to evaluate their affinities with extant taxa. Using landmark-based geometric morphometric analyses of the forewing shape and morphology, we estimate the similarity/dissimilarity of the fossil wing shape with extant and extinct bee taxa, particularly other corbiculate bees (Apinae: Corbiculata). Based on the results of the forewing shape comparisons, we propose a new taxonomic arrangement for many of the fossils. Based on our revised system we re-examined whether these few occurrences have any impact on understanding the diversification and extinction patterns of bumble bees.

\section{Materials and methods}

\section{Type revision, morphological terminology, and classification}

We examined all of the fossils described in the literature as bumble bees or as closely allied extinct genera (Table 1), corresponding to 15 specimens representing 14 described species. For all species, we tried to locate the type material to check against the original description and to better illustrate the fossil, if needed. We contacted the potential repositories of the fossils and were able to locate 13 specimens for review (Fig. 1). Information about museum repositories is included in the "Results" section. Overall, we gathered pictures and/or drawings of the forewings of 13 specimens representing 12 of 14 species (Table 1 ).

The morphological terminology follows that of Engel (2001) and Michener (2007), while the higher classification (i.e., subfamily, tribe) follows that of Michener (2007) (i.e., seven families: Andrenidae, Apidae, Colletidae, Halictidae, Megachilidae, Melittidae, and Stenotritidae). For bumble bees, we used the subgeneric system of Williams et al. (2008) where 15 subgenera were proposed. A complete list of extant species with their nomenclature is available at the following link (updated from Williams 1998): (http://www.nhm.ac.uk/research-curation/research/projects/bombus/groups.html).

\section{Geological settings}

Fossils of bumble bees have been described from eleven deposits from the Late Eocene to the Upper Miocene: Brembridge Marls, Florissant, BesKonak, Latah, Bílina Mine, Krottensee, Randeck Maar, Shandong, Botchi River, Euboea, and La Cerdanya (Table 1). 


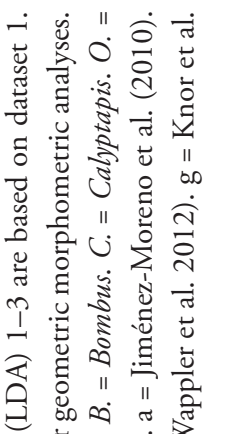

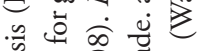

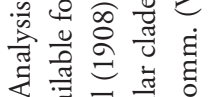

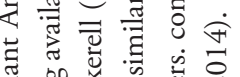
త્ઢ (1) 政

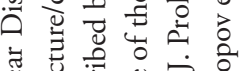

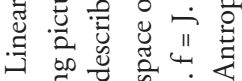

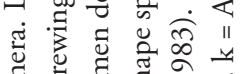

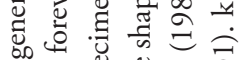

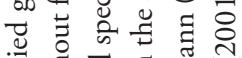

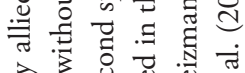

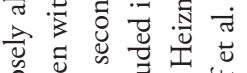
혼 ๙ के

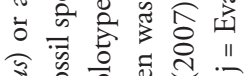

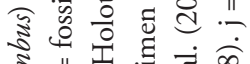
초ำ" का

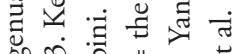

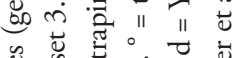

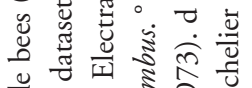

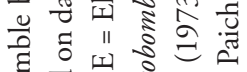

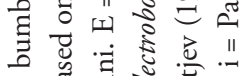

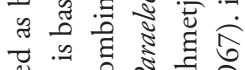

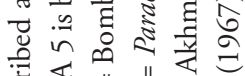

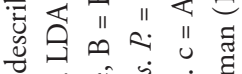

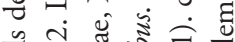

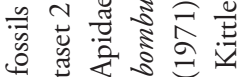
ह है

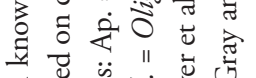

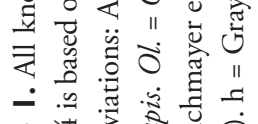

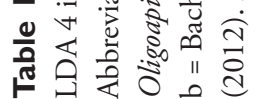

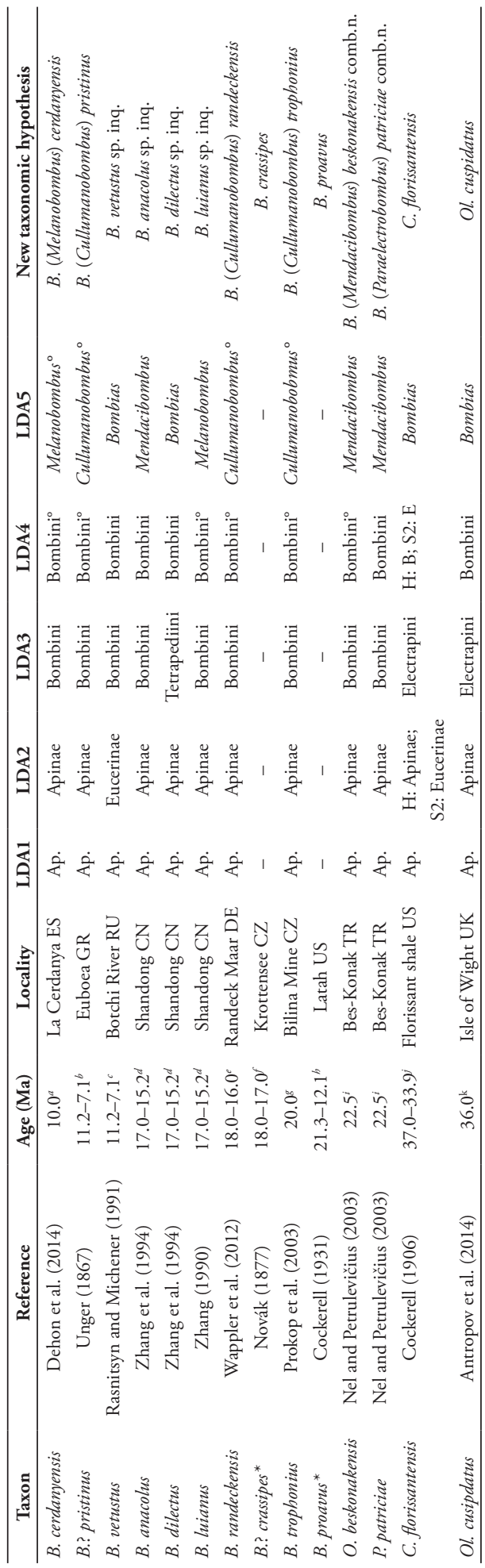


The Insect Bed of the Bembridge Marls from the Late Eocene (i.e., 36.0 Ma) is located on the Isle of Wight (UK). Two bee fossils were recorded from the deposit: the presumed bombine Oligobombus cuspidatus Antropov, 2014 and specimen NHMUK In.10012 (Megachilidae, incertae sedis) (Antropov et al. 2014).

The Florissant shale of Colorado (USA) (Swisher and Prothero 1990), situated near the Eocene-Oligocene boundary is approximately 34.0 Ma in age (Epis and Chapin 1974; Evanoff et al. 2001; Boyle et al. 2008; Mustoe 2008; Veatch and Meyer 2008). It produced a large number of the known bee fossils, most of which were described in the early part of the $20^{\text {th }}$ Century, with 36 specimens representing 34 species in 19 genera (Zeuner and Manning 1976; Michez et al. 2012). One possible bumble bee fossil was recorded: Calyptapis florissantensis Cockerell, 1906.

The deposits of BesKonak are from the Lower Miocene (Aquitanian, i.e., 22.5 Ma) and located in Anatolia, north of Ankara Province, Turkey (Paichelier et al. 1978). The only bombine fossils discovered in the deposits of BesKonak are Oligoapis beskonakensis Nel \& Petrulevičius, 2003 and Paraelectrobombus patriciae Nel \& Petrulevičius, 2003.

The Latah Formation encompasses the Lower to Middle Miocene (i.e., 21.3-12.1 Ma) of eastern Washington and northwestern Idaho (USA) (Berry 1929; Kirkham and Melville 1929; Gray and Kittleman 1967; Lewis 1969; Robinson 1991; Derkey et al. 2003). The only known bee fossils from this deposit are Bombus proavus Cockerell, 1931 and an undetermined megachiline specimen (Cockerell 1931; Engel 2004).

The deposits of the Most Formation at Bílina Mine date from the Lower Miocene (i.e., 20.0 Ma), in northern Bohemia (Czech Republic) (Kvaček 1998; Prokop and Nel 2000; Prokop et al. 2003; Kvaček et al. 2004; Knor et al. 2012). Two bee fossils have been reported from the deposits of the Most Formation: undetermined specimens of Apis and the bumble bee B. trophonius Prokop, Dehon, Michez \& Engel, 2017 (Prokop et al. 2003; Prokop et al. 2017; Engel pers. obs.).

Krottensee, also in the Czech Republic, dates from the Lower Miocene (i.e., 18.0 17.0 Ma), and is also referred to as Mokřina (Bůžek et al. 1996; Mlíkovský 1996; Rojík 2004). A single bumble bee has been recovered from the deposits, B. crassipes Novák, 1878 (Novák 1878; Krzemiński and Prokop 2011).

The Randeck Maar deposits of the Lower-Middle Miocene (i.e.,18.0-16.0 Ma) are located in southwestern Germany, southeast of Stuttgart at the escarpment of the Swabian Alps (Heizmann 1983), and is the largest ancient Maar in that region (Köppen and Geiger 1928; Gregor 1986; Krautter and Schweigert 1991; Schweigert 1998; Lutz et al. 2000; Kottek et al. 2006). This fossil Lagerstätte contains exceptionally well-preserved flora and fauna (e.g., Armbruster 1938; Gregor 1986; Schawaller 1986; Ansorge and Kohring 1995; Kotthoff 2005; Kotthoff and Schmid 2005; Kotthoff et al. 2011). Several prominent bee fossils have been reported from Randeck Maar - Apis armbrusteri Zeuner, 1931 (Kotthoff et al. 2011), B. randeckensis Wappler \& Engel, 2012 (Wappler et al. 2012), and Halictus schemppi (Armbuster, 1938) - and while those of Bombus and Halictus are each from single specimens, a plethora of honey bee workers have been recorded (Kotthoff et al. 2011). 
The Middle Miocene sediments of the Shanwang Formation (17.0-15.2 Ma) are located in Linqu County, Shandong Province, China (Yang et al. 2007). Many insects have been listed from this deposit, including bees (Megachilidae, Apidae), and specifically the bumble bees $B$. anacolus Zhang, $B$. luianus Zhang, and $B$. dilectus Zhang (Zhang 1990; Zhang et al. 1994).

The Botchi Formation is from the Upper Miocene (i.e., 11.2-7.1 Ma) and is located on the left bank of the Botchi River in Russia (Khabarovsk Region) (Akhmetjev 1973). This formation has yielded various plants, fishes, Crustacea, and insects, including B. vetustus Rasnitsyn \& Michener, 1991.

The deposit of Kumi (Euboea, Greece) is from the Middle-Upper Miocene (i.e., 11.2-7.1 Ma). Insects from the orders Coleoptera, Diptera, and Hymenoptera were discovered in the Kumi deposit, and these included B. pristinus Unger, 1867.

The Spanish deposit of La Cerdanya corresponds to Upper Miocene lacustrine beds (i.e., 10.0 Ma) located in Spain (Lleida, Bellver-en-Cerdaña) (Diéguez et al. 1996; Jiménez-Moreno et al. 2010). The flora and entomofauna are quite abundant and diverse (Peñalver-Molla et al. 1999; Arillo 2001) with a rather high occurrence of bees, although nearly all specimens belong to Apis (Nel et al. 1999). Bombus cerdanyensis Dehon, De Meulemeester \& Engel, 2014 was described from this deposit (Dehon et al. 2014).

\section{Geometric morphometric analyses of forewing shape}

We performed geometric morphometric analyses of the forewing shape in order to assess the taxonomic affinities of 12 bumble bee fossil species (13 specimens) showing well-preserved forewings (Fig. 1). This tool is useful in insect taxonomy for discriminating and diagnosing taxa at different levels (e.g., Pretorius 2005; Petit et al. 2006; Francoy et al. 2009, 2012; Sadeghi et al. 2009; Perrard et al. 2014; Van Cann et al. 2015), as well as in paleontology for assessing taxonomic affinities of fossils with contemporary and extinct taxa (e.g., Kennedy et al. 2009; Michez et al. 2009a; De Meulemeester et al. 2012; Wappler et al. 2012; Dehon et al. 2014, 2017; Dewulf et al. 2014; Perrard et al. 2016; Prokop et al. 2017). Several studies have demonstrated the utility of forewing shape analyses for diagnosing subgenera, species, and populations of bumble bees, depending on rearing conditions (e.g., Aytekin et al. 2007; Wappler et al. 2012; Barkan and Aytekin 2013; Gérard et al. 2018).

We used three different datasets to assess the taxonomic affinities of the fossils at different taxonomic levels. All three datasets represent a sampling of contemporary and extinct tribes with three submarginal cells, were largely assembled and analyzed in previous studies (i.e., Dehon et al. (2017) for the first dataset and Prokop et al. (2017) for the second and third datasets). We only (i) modified the classification of the species in the different datasets based on Bossert et al. (2019) and (ii) added the 13 fossils in each of these datasets. The first dataset included a comprehensive sampling of bee tribes in order to ensure correct tribal placement of the 13 fossils. This dataset consisted 
of 50 tribes representing 226 species and 979 specimens (refer to Dehon et al. (2017) for full details; Suppl material 1: Table S1). It also uncovered a group of six tribes (i.e., Ancylaini, Electrapini, Emphorini, Euglossini, Melikertini, and Tetrapediini) showing similar wing shapes to Bombini. We then used a second dataset with more extensive sampling within Bombini and these six similar tribes. This second dataset was assembled and tested by Prokop et al. (2017). It includes 841 specimens and represents all 15 subgenera and 210 species of extant bumble bees ( $80 \%$ of the total species diversity) as well as tribes Ancylaini, Electrapini, Emphorini, Euglossini, Melikertini, and Tetrapediini, representing a further 18 genera, 43 species, and 132 specimens altogether (Suppl material 2: Table S2). Finally, fossils confirmed to belong to Bombini using the first and second datasets were compared to a third dataset that only consists of the bumble bee specimens of the second dataset in order to assess the taxonomic affinities of the specimens with extant subgenera of Bombus. Dehon et al. (2017) (Suppl materials 3-5: Tables S3-S5) and Prokop et al. (2017) (Suppl materials 6-7: Tables S6-S7) demonstrated reliability for these datasets in classifying bee specimens based on forewing shape similarity relative to the reference datasets of forewings. Hence, the crossvalidation allows us to be confident in the discrimination.

The potential effect of sexual dimorphism on subgeneric assignment using wing morphometry was tested by Wappler et al. (2012) for the subgenus Bombus s. str. For this subgenus, the results showed that sexual dimorphism had limited impact on subgeneric assignment. We tested it on four additional subgenera (based on 82 specimens from 12 species of four subgenera: Bombias, Cullumanobombus, Melanobombus, and Mendacibombus); the identification of the subgenera based on wing shape was again highly supported (Suppl material 7: Table S7). Therefore, to limit intraspecific variability in our dataset, we sampled female specimens only. We selected females because Bombini are mostly social species and workers (i.e., females) are the most abundant caste. Moreover, most of the known fossil specimens are females, although the holotype of $B$. vetustus is a male as evidenced by the lack of a corbicula, male flagellomeres, etc. (Rasnitsyn and Michener 1991).

Left forewings were photographed using an Olympus SZH10 microscope combined with a Nikon D200 camera. Photographs were then uploaded in the software tpsUTIL 1.69 (Rohlf 2013a). The forewing shape was captured by digitizing twodimensional Cartesian coordinates of 18 landmarks on the wing veins and cells (Fig. 4) with the software tpsDIG version 2.27 (Rohlf 2013b). Position of the landmarks was based on Owen (2012) and other studies like De Meulemeester et al. (2012), Wappler et al. (2012), Dewulf et al. (2014), Dehon et al. (2014, 2017), Gérard et al. (2015), and Prokop et al. (2017). The two-dimensional configurations of the landmarks were superimposed using the GLS Procrustes superimposition in the software $\mathrm{R}$ version 3.0.2 (Rohlf and Slice 1990; Bookstein 1991; Adams and Otárola-Castillo 2013; R Development Core Team 2013). The closeness of the tangent space to the curved shape space was analyzed by calculating the least-squares regression slope and the correlation coefficient between the Procrustes distances (in the shape space) and the Euclidean distances (in the tangent space) (Rohlf 1999). This was calculated using the software tpsSMALL v1.25 (Rohlf 2013c). 


\section{Shape discrimination at different taxonomic levels}

Variation of shape in the dataset was explored with PCA analyses to visualize clustering and detect outliers (Fig. 5). Discrimination of the wing shape of the different taxa was assessed by Linear Discriminant Analyses (LDA) of the projected aligned configuration of landmarks like in Prokop et al. (2017). We performed three LDAs with the first dataset (Dehon et al. 2017, Suppl material 1: Table S1) with different levels a priori grouping (i.e., the groups are known a priori by the analysis): family, subfamily and tribe (LDA 1-3, Tables 1, Suppl materials 3-5). We did a fourth LDA analysis with the second dataset (i.e., bumble bees + six similar tribes, Suppl material 2: Table S2) with tribe level as a priori grouping (LDA 4, Table 1, Suppl material 6). Finally, we used a comprehensive sampling of extant bumble bees (i.e., third dataset, Suppl material 2: Table S2) for a fifth LDA considering the subgenus level as a priori grouping (LDA 5, Tables 1, Suppl material 7: Table S7). The LDA effectiveness was assessed by the percentages of individuals correctly classified to their original taxon (hit-ratio, HR) in a leave-one-out (LOO) cross-validation procedure based on the posterior probabilities of assignment (Suppl materials 3-7: Tables S3-S7). Given the observed scores of an "unknown", the posterior probability (pp) equals the probability of the unit to belong to one group compared to all others. The unit is consequently assigned to the group for which the posterior probability is the highest (Huberty and Olejnik 2006). All discriminant analyses were performed using the $\mathrm{R}$ software (R Development Core Team 2013).

\section{Assignment of the bee fossils}

Taxonomic affinities of the fossils were assessed based on the score in the predictive discriminant space of shapes. Aligned coordinates of the specimens from the three datasets (including the fossils) were used to calculate the same five LDA as presented in the previous section. Assignment of the fossils was estimated by calculating the Mahalanobis Distance between each fossil and group mean of each taxon and then assigning it to the nearest group in the discriminant shape of the LDA (Suppl materials 7-12: Tables S7-S12). Principal Component Analyses (PCA) were also computed to visualize shape affinities between the fossils and the extant groups in the second dataset (Fig. 5). Mahalanobis Distance is well suited for dealing with large datasets of close-relative taxa (Claude 2008).

\section{Results}

\section{Geometric morphometric analyses}

The assignment of each fossil was assessed in each dataset. When using the first dataset, all fossils were assigned to Apidae, more specifically to Apinae (except for the second specimen of $C$. florissantensis described by Cockerell (1908) and B. vetustus, both assigned to Eucerinae) and to Bombini (except for $B$. dilectus assigned to Tetrapediini, 
and Oligobombus cuspidatus and both specimens of $C$. florissantensis, all three assigned to Electrapini) (see LDA 1-3, Tables 1, Suppl materials 9-11). We then specifically assessed the assignment of each fossils based on the second and the third dataset. Oligobombus cuspidatus and both specimens of $C$. florissantensis were close to the shape space of contemporary Bombini, while being placed outside of contemporary Bombini and fossil Electrapini (Dataset 2, LDA 4). Among bombine subgenera, Bombias was most similar in forewing shape to Oligobombus and Calyptapis (Dataset 3, LDA 5). Based on our discriminant analyses, Paraelectrobombus patriciae was also similar to extant Bombini while being just outside of its shape space (Dataset 2, LDA 4). Bombus beskonakensis clustered within the shape space of extant Bombini (Dataset 2, LDA 4) and was similar to the subgenus Mendacibombus but outside the modern shape space of that subgenus (Dataset 3 , LDA 5). The assignment of $B$. trophonius based on wing shape was already assessed in Prokop et al. (2017), this fossil clustered within contemporary Cullumanobombus (Dataset 3, LDA 5). The forewing shape of B. randeckensis was previously analyzed by Wappler et al. (2012) who proposed that the specimen was close to the subgenus Bombus s. str. Our analyses found a close similarity with Cullumanobombus (Dataset 3, LDA 5), while in Wappler et al. (2012) this subgenus was the fourth most similar subgenus to the fossil. This discrepancy may be explained by the fact that we used a larger and more diverse dataset, or possibly also because forewings were digitized by different experimenters in both studies. Bombus luianus clustered within Bombini based on its forewing shape (Dataset 2, LDA 4). Moreover, its forewing shape was similar to, but outside of modern Melanobombus, suggesting this fossil might be sister to extant Melanobombus (Dataset 3, LDA 5). Bombus dilectus did not cluster within the shape space of Bombini, but the tribe was the most similar (Dataset 2, LDA 4), but it is possible the published drawings are not entirely accurate. The most similar subgenus was the subgenus Bombias (Dataset 2, LDA 4), one of the most basal subgenera of the genus (Fig. 5). Bombus anacolus clustered just outside of crown-group Bombini while being quite similar to this tribe based on its forewing shape (Dataset 2, LDA 4), but again the published drawing is rather poor. Nonetheless, its forewing shape was similar to modern Mendacibombus (Dataset 3, LDA 5). Bombus vetustus, which is a male, was most similar to the tribe Bombini based on forewing shape but was placed outside of the shape space of modern Bombini (Dataset 2, LDA 4). Despite this, the most similar subgenus was Bombias (Dataset 3, LDA 5). There is only one specimen available of $B$. pristinus, which has incomplete wings. However, all landmarks are available except for number 16, whose position could be accurately estimated by the extension of cu-a and portion of vein A. We decided therefore to apply the same LDA analyses to the specimen, with the 18 landmarks. Our results found that this fossil clustered inside the shape space of Bombini (Dataset 2, LDA 4) and was similar to the subgenus Cullumanobombus (Dataset 3, LDA 5), although it would be worth reanalyzing this specimen with a dataset encompassing males from extant species in order to have greater confidence. Finally, the wing shape of $B$. cerdanyensis was first analyzed in Dehon et al. (2014). This specimen has incomplete wings; nonetheless, all landmarks are available except for numbers 17 and 18, but the position of the latter could be accurately estimated by the extension of $\mathrm{cu}-\mathrm{a}$ and portion of vein A. Assignment of the fossil in the discriminant space did not allow a reliable subgeneric attribution. Herein, B. cerdanyensis 
is assigned to Melanobombus (Dataset 3, LDA 5). The subgeneric assignment of each fossil within Bombus s. 1. through geometric morphometric analyses is summarized in Table 1.

\section{Systematics}

In the following account of fossil bombine species, we have organized the taxa by general age, proceeding from oldest to youngest.

\section{Family Apidae Latreille}

Subfamily Apinae Latreille

Clade Corbiculata Engel

Stem-group Bombini Latreille

\section{Late Eocene}

\section{Genus Oligobombus Antropov, 2014}

Type species. Oligobombus cuspidatus Antropov, 2014, by original designation.

Diagnosis. Sex unknown. Forewing distinctly pointed apically (apparently taphonomically altered); three submarginal cells of approximately equal sizes; marginal cell elongate, longer than distance between its apex and forewing tip, with apex roundly truncate; forewing distal membrane papillate; pterostigma short, with margin within marginal cell straight, approximately 4.0 times as long as prestigma; r-rs arising from distal part of pterostigma after its midpoint; $1 \mathrm{rs}-\mathrm{m}$ straight; $2 \mathrm{rs}-\mathrm{m}$ with posterior half curved apically; angle between $1 \mathrm{rs}-\mathrm{m}$ and part of $\mathrm{M}$ inside third submarginal cell obtuse; first submarginal cell with an oblique translucent vein rs and not wider than second submarginal cell; second submarginal cell shorter than third marginal cell; third submarginal cell widest; $1 \mathrm{~m}$-cu slightly curved anteriorly, reaching second submarginal cell in its midpoint; $2 \mathrm{~m}$-cu curved anteriorly, reaching $\mathrm{M}$ basad 2rs-m; distance between anterior ends of $1 \mathrm{~m}$-cu and $2 \mathrm{~m}$-cu exceeding their length; basal vein slightly basad cu-a. See Antropov et al. (2014) for original diagnosis.

\section{Oligobombus cuspidatus Antropov, 2014}

Holotype. Sex unknown. NHMUK In.17349 (part and counterpart), Smith collection of the Natural History Museum (NHM, London, UK). Type specimen has been located and revised (Figs 1A, 3A).

Type strata and locality. Late Eocene (i.e., 36.0 Ma), Insect Bed of the Bembridge Marls from the Isle of Wight, UK. 

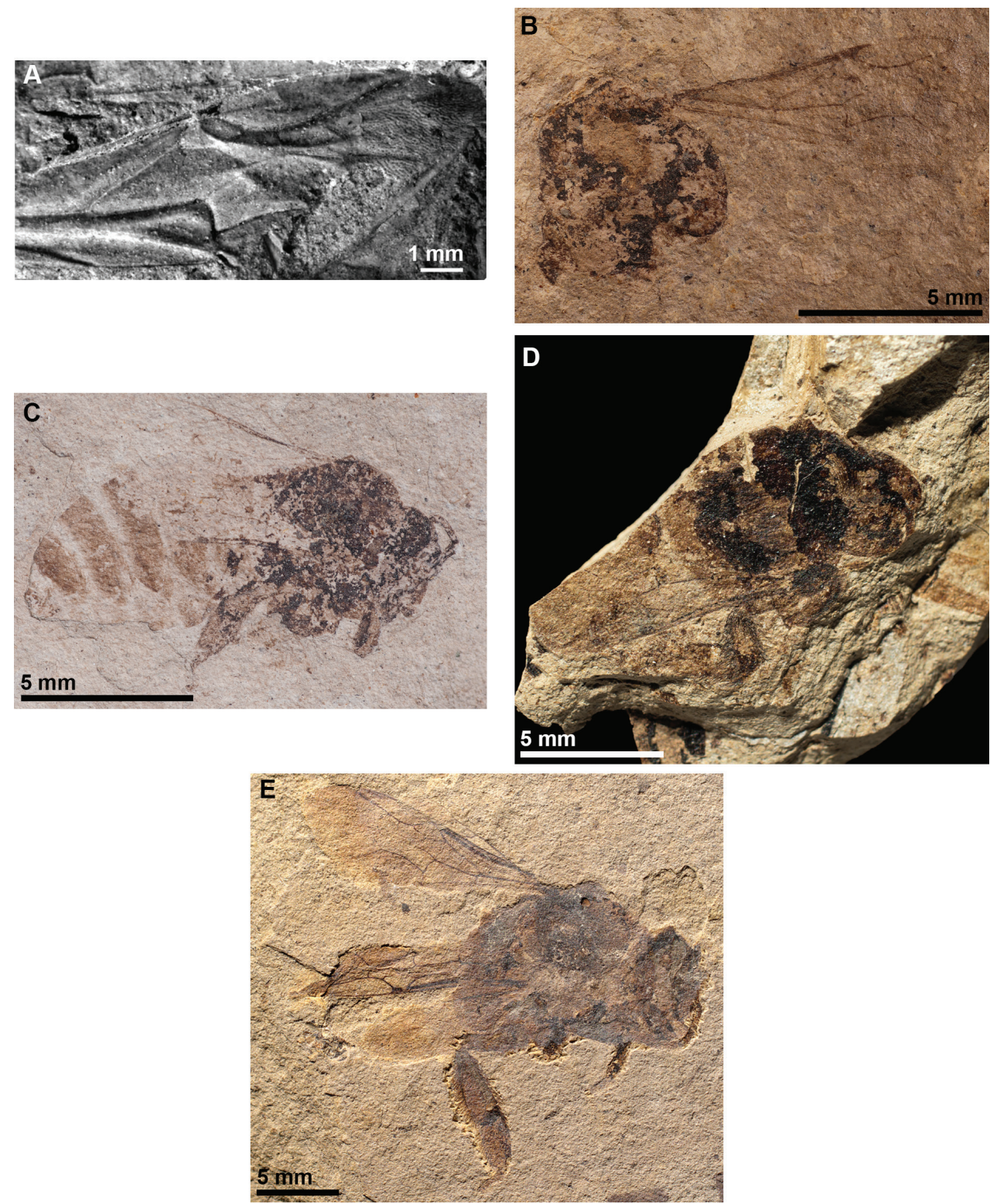

Figure I. Representative fossil bumble bees A Oligobombus cuspidatus (photograph by Antropov et al. (2014)) B Holotype of Calyptapis florissantensis (photograph by Manuel Dehon) C C. florissantensis (photograph by Talia S. Karim) D Bombus (Paraelectrobombus) patriciae (photograph by Gaëlle Doitteau) E B. (Mendacibombus) beskonakensis (photograph by Gaëlle Doitteau).

Diagnosis. Owing to monotypy, the diagnosis for the species is identical to that of the genus (vide supra).

Description. Part consists in middle and apical parts of right forewing; counterpart consists of middle part of right forewing; forewing distal membrane papillate; complete venation preserved; total forewing length $13.3 \mathrm{~mm}$, maximum width $4.0 \mathrm{~mm}$ as pre- 
served; basal vein length $2.3 \mathrm{~mm}$, relatively straight and basad cu-a; cu-a length $0.3 \mathrm{~mm}$; marginal cell length $4.0 \mathrm{~mm}$, width $0.9 \mathrm{~mm}$, apex roundly truncate; prestigma $0.2 \mathrm{~mm}$; pterostigma length $0.8 \mathrm{~mm} ; 1^{\text {st }}$ abscissa of Rs straight; $2^{\text {nd }}$ abscissa of Rs almost straight; 3Rs length approximately same as r-rs; 4Rs slightly longer than 3Rs; $M+R s$ length 1.2 $\mathrm{mm}$; three submarginal cells; first submarginal cell length $1.5 \mathrm{~mm}$ (as measured from origin of Rs+M to juncture of $\mathrm{r}-\mathrm{rs}$ and Rs), width $0.6 \mathrm{~mm}$ (as measured from Rs+M to pterostigma); second submarginal cell length $1.3 \mathrm{~mm}$ (as measured from juncture of Rs+M and $\mathrm{M}$ to juncture of Rs and 1 rs-m), width $0.7 \mathrm{~mm}$ (as measured from midpoint on $\mathrm{M}$ between $1 \mathrm{~m}-\mathrm{cu}$ and $1 \mathrm{rs}-\mathrm{m}$ to juncture of $\mathrm{r}-\mathrm{rs}$ and Rs); third submarginal cell length $1.4 \mathrm{~mm}$ (as measured from juncture of $1 \mathrm{rs}-\mathrm{m}$ and $\mathrm{M}$ to juncture of $\mathrm{M}$ and 2rs$\mathrm{m}$ ), width $1.0 \mathrm{~mm}$ (as measured from juncture of $\mathrm{M}$ and $2 \mathrm{~m}$-cu to juncture of $2 \mathrm{rs}-\mathrm{m}$ and Rs); 1rs-m straight; $2 \mathrm{rs}-\mathrm{m}$ posterior half curved apically; $1 \mathrm{~m}$-cu anterior half curved apically, reaching $\mathrm{M}$ approximately at midpoint between $2^{\text {nd }}$ abscissa of Rs and 1rs-m; 2m-cu basad 2rs-m. See Antropov et al. (2014) for original description.

Comments. There is only one specimen, the holotype NHMUK In.17349, consisting of a part and counterpart. Antropov et al. (2014) described the specimen and considered it as possibly a member of Bombini. According to the original author, the forewing shape displays mixed features of Bombini, Electrapini, Electrobombini, Euglossini, and Melikertini (e.g., the forewing distal membrane being papillate is characteristic of Bombini, Electrobombini, and Euglossini, the shape of vein Rs displays mixed features reminiscent of the corbiculate tribes Bombini, Electrobombini, Electrapini (i.e., Thaumastobombus Engel, 2001), Euglossini, and Melikertini (i.e., Melikertes Engel, 1998 and Succinapis Engel, 2001), the submarginal cells are reminiscent of Electrapini, Electrobombini, and Euglossini, 1m-cu is reminiscent of Electrapini and Electrobombini, $2 \mathrm{~m}$-cu is reminiscent of Electrapini, Euglossini, and Melikertini). All in all, the specimen has a forewing venation with features that can be found in different extinct and extant tribes of Corbiculata, but that taken together do not occur in any of them. According to the Antropov et al. (2014), the fossil forewing venation is generally similar to extant species of Bombini, but the lack of features from the pro-, meso-, and metasoma prevents identification of its exact taxonomic affinities. Based on the general morphology and forewing shape affinities, Oligobombus is perhaps a stem-group bombine and we consider it as such for the moment. Further material and additional characters, ideally analyzed in a cladistic framework, are needed to corroborate this placement, or the species could have phylogenetic affinities with Electrobombini or Electrapini.

\section{Eocene-Oligocene boundary}

\section{Genus Calyptapis Cockerell, 1906}

Type species. Calyptapis florissantensis Cockerell, 1906, by original designation.

Diagnosis. Three submarginal cells; third submarginal cell longest, shorter than combined length of first and second submarginal cells; first and second submarginal cells of more or less same size; first submarginal cell rounded; marginal cell wide, 
apex rounded and scarcely offset from anterior forewing margin; basal vein long and straight, slightly curved in its base, meeting $\mathrm{M}+\mathrm{Cu}$ near juncture of cu-a with $\mathrm{M}+\mathrm{Cu}$; cu-a slightly curved; $1 \mathrm{~m}$-cu meeting $\mathrm{M}$ at middle of second submarginal cell; $2 \mathrm{~m}-\mathrm{cu}$ slightly curved and not in line with 2rs-m, positioned before crossing between 2rs-m and $\mathrm{M} ; 2 \mathrm{rs}-\mathrm{m}$ strongly arched; 2 Rs scarcely arched basally; pterostigma relatively small. Pro- and mesosoma black; corbicula preserved; no alar papillae (or, more likely, not visible as preserved); forewing not colored. Similar in forewing venation to Bombus s. 1. but differing from most species in the combination of a simultaneously distally bulging third submarginal cell (i.e., 2rs-m strongly arched), with a relatively unmodified second submarginal cell (i.e., 2Rs scarcely arched basally, a putatively plesiomorphic trait and somewhat similar to many euglossines), and broad marginal cell apex that is scarcely offset from anterior wing margin.

\section{Calyptapis florissantensis Cockerell, 1906}

Holotype. Sex unknown. MCZPALE 2008, collections of the Museum of Comparative Zoology (Harvard University, Cambridge, USA). Samuel Hubbard Scudder collection. Type specimen has been located and revised (Figs 1B, 3B).

Type strata and locality. Eocene-Oligocene boundary (i.e., 34.0 Ma), the Florissant shale of Colorado, USA.

Diagnosis. Owing to monotypy, the diagnosis for the species is identical to that of the genus (vide supra).

Description. Integument of body black to dark brown as preserved (taphonomically altered); forewing venation brown to dark brown, membrane hyaline as preserved; forewing length $7.6 \mathrm{~mm}$; maximum width approximately $2.5 \mathrm{~mm}$ as preserved; basal vein (1M) faintly arched at base, straight along length, basad $1 \mathrm{cu}-\mathrm{a}$ by about twice vein width, faintly angled relative to $1 \mathrm{Rs}$; Rs+M originating anteriad, $1 \mathrm{Rs}$ about as long as r-rs; pterostigma short, slightly longer than wide, border inside marginal cell slightly concave, prestigma very short, scarcely present, about as long as $2.5-3$ times width of 1Rs; marginal cell length $2.2 \mathrm{~mm}$, width $0.5 \mathrm{~mm}$, tapering slightly across its length, free portion of cell subequal to portion bordering submarginal cells, apex rounded and offset from anterior wing margin by about vein width, not appendiculate; 2 Rs weakly arched basally, comparatively straight; $r-r$ about as long as 3Rs; 4Rs slightly longer than 3Rs; three submarginal cells of comparatively similar sizes, albeit third slightly larger than first or second, but slightly shorter than combined lengths of first and second submarginal cells; first submarginal cell length $0.9 \mathrm{~mm}$ (as measured from origin of Rs+M to juncture of $\mathrm{r}$-rs and Rs), width $0.4 \mathrm{~mm}$ (as measured from Rs+M to pterostigma); second submarginal cell length $0.7 \mathrm{~mm}$ (as measured from juncture of Rs+M and $\mathrm{M}$ to juncture of Rs and $1 \mathrm{rs}-\mathrm{m}$ ), width $0.4 \mathrm{~mm}$ (as measured from midpoint on $\mathrm{M}$ between $1 \mathrm{~m}$-cu and $1 \mathrm{rs}-\mathrm{m}$ to juncture of $\mathrm{r}$-rs and Rs); third submarginal cell length 0.9 $\mathrm{mm}$ (as measured from juncture of $1 \mathrm{rs}-\mathrm{m}$ and $\mathrm{M}$ to juncture of $\mathrm{M}$ and $2 \mathrm{rs}-\mathrm{m}$ ), width $0.6 \mathrm{~mm}$ (as measured from juncture of $\mathrm{M}$ and $2 \mathrm{~m}$-cu to juncture of $2 \mathrm{rs}-\mathrm{m}$ and $\mathrm{Rs}$ ); 
1rs-m weakly arched; 2rs-m strongly arched distally in posterior half, such that third submarginal cell is greatly bulged distally; $1 \mathrm{~m}$-cu distinctly angulate anteriorly near $\mathrm{M}$, entering second submarginal cell slightly before cell's midlength; $2 \mathrm{~m}$-cu weakly and gently arched apically, meeting third submarginal cell near cell's apex, basad 2rs-m by about 2.5 times vein width; mesosoma length $4.4 \mathrm{~mm}$ as preserved; metasoma length $8.8 \mathrm{~mm}$ as preserved; total body length $15.2 \mathrm{~mm}$ as preserved. Specimen UCM 4415: left lateral view; pro-, meso-, and metasoma preserved, both forewings preserved; parts of right hindleg and foreleg preserved; forewing venation preserved; part of one antenna preserved. Specimen MCZPALE-2008: mesosoma preserved, as well as part of prosoma; right forewing visible. See Cockerell $(1906,1908 c)$ for original description.

Comments. Calyptapis florissantensis was first described based on a poorly preserved specimen collected by Samuel H. Scudder (MCZPALE 2008), and was first attributed to Eucerini by Cockerell (1906). The well-preserved second specimen (UCM 4415) was described by Cockerell (1908) and this permitted him to attribute both specimens to Bombini. However, he stated that the fossil differed from extant Bombus in the form of the second and third submarginal cells, thus suggesting it to be a member of a genus close to Bombus (Cockerell 1906, 1908; Zeuner and Manning 1976). Based on the general morphology and forewing shape affinities, Calyptapis is perhaps a stem-group bombine and we consider it as such for the moment, although a cladistic analysis encompassing additional characters is needed for a more definitive clarification of its phylogenetic affinities.

\section{Oligocene-Miocene boundary}

\section{Tribe Bombini Latreille \\ Genus Bombus Latreille \\ Subgenus Paraelectrobombus Nel \& Petrulevičius, 2003, nomen translatum}

Type species. Paraelectrobombus patriciae Nel \& Petrulevičius, 2003.

Diagnosis. Bombiform bee; pterostigma larger than prestigma; vein $1 \mathrm{~m}$-cu curved apically in its anterior half; vein r-rs reaching pterostigma at midpoint; second abscissa of Rs relatively straight; vein 2rs-m curved apically in its posterior half; vein $2 \mathrm{~m}$-cu slightly curved at midpoint, reaching $\mathrm{M}$ basad to 2rs-m; two tibial spurs; corbicula with setae longer than metatibia width. See Nel and Petrulevičius (2003) for original diagnosis.

\section{Bombus (Paraelectrobombus) patriciae (Nel \& Petrulevičius, 2003), comb. nov.}

Holotype. Female. MNHN-LP-R. 11187 (coll. Paichelier 1977), deposited in the Laboratoire de Palaeontologie, Muséum national d'Histoire naturelle, Paris, France. The type specimen was located, examined, and revised (Figs 1D, 3D). 
Type strata and locality. Oligocene-Miocene boundary, 22.5 Ma, volcano-sedimentary paleolake deposit, BesKonak Basin, Anatolia, Turkey.

Diagnosis. Owing to monotypy, the diagnosis for the species is identical to that of the subgenus (vide supra).

Description. Body poorly preserved and covered with long setae; forewing membrane hyaline and covered with small pilosity, venation similar to that of extant species of Bombus s. l.; forewing length $9.0 \mathrm{~mm}$, maximum width approximately $3.4 \mathrm{~mm}$ as preserved; basal vein slightly curved at base, and slightly basad cu-a, length $1.9 \mathrm{~mm}$; prestigma length $0.3 \mathrm{~mm}$, width $0.2 \mathrm{~mm}$; pterostigma length $0.6 \mathrm{~mm}$, width $0.3 \mathrm{~mm}$; marginal cell length $2.8 \mathrm{~mm}$, width $0.6 \mathrm{~mm}$, with apex narrowly rounded and detached from margin of forewing; $1^{\text {st }}$ abscissa of Rs straight; $2^{\text {nd }}$ abscissa of Rs curved basally in its last posterior part; r-rs almost straight; 3Rs smaller than r-rs; 4Rs approximately as long as r-rs; Rs+M straight and longer than r-rs; three submarginal cells of approximately equivalent size; first submarginal cell length $1.4 \mathrm{~mm}$ (as measured from origin of $\mathrm{Rs}+\mathrm{M}$ to juncture of $\mathrm{r}-\mathrm{rs}$ and $\mathrm{Rs}$ ), width $0.6 \mathrm{~mm}$ (as measured from Rs+M to pterostigma); second submarginal cell length $1.1 \mathrm{~mm}$ (as measured from juncture of Rs+M and $\mathrm{M}$ to juncture of Rs and 1rs- $\mathrm{m}$ ), width $0.6 \mathrm{~mm}$ (as measured from midpoint on $\mathrm{M}$ between $1 \mathrm{~m}-\mathrm{cu}$ and $1 \mathrm{rs}-\mathrm{m}$ to juncture of $\mathrm{r}-\mathrm{rs}$ and $\mathrm{Rs}$ ); third submarginal cell length $1.0 \mathrm{~mm}$ (as measured from juncture of $1 \mathrm{rs}-\mathrm{m}$ and $\mathrm{M}$ to juncture of $\mathrm{M}$ and $2 \mathrm{rs}-\mathrm{m}$ ), width $0.8 \mathrm{~mm}$ (as measured from juncture of $\mathrm{M}$ and $2 \mathrm{~m}-\mathrm{cu}$ to juncture of $2 \mathrm{rs}-$ $\mathrm{m}$ and Rs); $1 \mathrm{rs}-\mathrm{m}$ almost straight; $2 \mathrm{rs}-\mathrm{m}$ with anterior half curved apically; $1 \mathrm{~m}$-cu with anterior half curved apically, reaching $\mathrm{M}$ slightly before midlength between $2^{\text {nd }}$ abscissa of Rs and 1rs-m; $2 \mathrm{~m}$-cu slightly curved near midpoint, reaching $\mathrm{M}$ basad 2rs-m; prosoma length $3.0 \mathrm{~mm}$ as preserved; mesosoma length $4.5 \mathrm{~mm}$ as preserved; metatibia without basal plate, length $2.2 \mathrm{~mm}$, width $0.6 \mathrm{~mm}$; corbicula with long setae; metabasitarsus length $2.0 \mathrm{~mm}$; width $1.0 \mathrm{~mm}$, with auricle at base; metasoma not preserved. The taphonomy of the specimen does not allow us to ascertain the presence or absence of a transector. See Nel and Petrulevičius (2003) for original description.

Comments. There is only one specimen, the holotype MNHN-LP-R. 11197. The fossil was initially described as Paraelectrobombus patriciae within the extinct tribe Electrobombini by Nel and Petrulevičius (2003), and was described as a bombine-like species with a wing venation similar to those of Bombini and Electrobombini. However, these authors stated that it was not possible to determine its exact relationship relative to Bombini and Electrobombini owing to the lack of information on its body structures such as the pretarsal claws and arolia. Based on the specimen's forewing shape affinities, Paralectrobombus is assuredly an extinct taxon of Bombini, and likely within the genus Bombus. Based on our results, we hypothesize that this group may be sister to extant Bombus or a stem group to Bombus.

\section{Subgenus Mendacibombus Skorikov, 1914}

= Oligoapis Nel \& Petrulevičius, 2003, syn. nov. 
Bombus (Mendacibombus) beskonakensis (Nel \& Petrulevičius, 2003), comb. nov.

Holotype. Female worker. MNHN-LP-B.47780 (BK349, coll. Paichelier, in 1977), part and counterpart, deposited in the Laboratoire de Palaeontologie, Muséum national d'Histoire naturelle, Paris, France. Type specimen has been located and revised (Figs 1E, 3E).

Type strata and locality. Oligocene-Miocene boundary, 22.5 Ma, volcano-sedimentary paleolake, BesKonak Basin, Anatolia, Turkey (Paichelier et al. 1978).

Diagnosis. Habitus and hind and forewing venation similar to those of extant Bombini, with pterostigma short but longer than prestigma, and metatibial spurs not visible as preserved (seemingly obscured by leg orientation). Short process of proximal posterior corner of metabasitarsus apparently preserved. See Nel and Petrulevičius (2003) for original diagnosis.

Description. Wing membrane red-brown, setose throughout; forewing length $15.0 \mathrm{~mm}$; maximum width $5.2 \mathrm{~mm}$ as preserved; pterostigma slightly longer than prestigma, with posterior margin aligned with vein $\mathrm{Sc}+\mathrm{R}$; marginal cell with apex closed by strong vein; three submarginal cells of approximately same size; basal vein long, oblique and slightly curved in its base, slightly basad cu-a; cu-a straight; $1 \mathrm{~m}$ cu strongly curved apically in its anterior half, reaching second submarginal cell near midpoint; $2 \mathrm{~m}$-cu curved apically, reaching $\mathrm{M}$ basad to 2rs-m; second abscissa of Rs slightly double-curved; $1 \mathrm{rs}-\mathrm{m}$ almost straight; $2 \mathrm{rs}-\mathrm{m}$ with posterior half curved apically; prosoma length $6.3 \mathrm{~mm}$, covered with long and dark hair; mouthparts not preserved, except for galea which is elongate; antennae approximately $3.5 \mathrm{~mm}$ long, with nine or ten visible flagellomeres, scape and pedicel poorly preserved; mesosoma length $8.0 \mathrm{~mm}$, height $5.0 \mathrm{~mm}$; metafemur length $4.2 \mathrm{~mm}$, width $1.4 \mathrm{~mm}$, with long curved hair; metatibia length $4.5 \mathrm{~mm}$, width $1.8 \mathrm{~mm}$, with corbicula; metabasitibial plate absent; metatibial spurs not visible as preserved (apparently owing to leg orientation); metabasitarsus length $2.7 \mathrm{~mm}$, width $1.7 \mathrm{~mm}$, with auricle preserved; arolia and claws not visible as preserved; metasoma length $9.0 \mathrm{~mm}$, height $4.5 \mathrm{~mm}$, covered with short setae. See Nel and Petrulevičius (2003) for original description.

Comments. The fossil was first described as Oligoapis beskonakensis by $\mathrm{Nel}$ and Petrulevičius (2003). The specimen is remarkably similar to extant Bombini in terms of its habitus and wing venation. However, the authors decided to place it in a separate genus of an undetermined corbiculate tribe owing to its pterostigma smaller than the prestigma, and by the putative absence of metatibial spurs. The absence of metatibial spurs is merely due to the lack of preservation and not to the definitive absence of spurs, and therefore this character cannot be evaluated. The metatibia is preserved with its outer surface exposed and the presence of spurs (particularly if they were reduced in size) on the inner anterior angle could not be observed in this orientation. In extant species of Mendacibombus, females are characterized by a few long bristles emerging from the outer surface of the metatibia, by a metatibia with the outer surface imbricate, i.e. coarsely sculptured, as well as by an unusually short (i.e., for Bombus s. 1.) process of the proximal posterior corner of the metabasitarsus (Williams et al. 2008, 2016). 
In the fossil, the long bristles emerging from the outer surface of the metatibia are not visible, while the short process of the proximal posterior corner of the metabasitarsus appears to be present. Furthermore, it is challenging to assess if the metatibia outer surface is coarsely sculptured due to the taphonomy of the specimen.

We consider the fossil as a stem group within Mendacibombus and thus synonymize Oligoapis under that subgenus. Like Oligoapis, Mendacibombus has a relatively reduced pterostigma, further emphasizing the similarity between these groups. Interestingly, this species from the Oligocene-Miocene boundary (i.e., 22.5 Ma) comes from a deposit near the estimated Old World origin of this subgenus (Williams et al. 2016). Because of the overall morphological assessment we place the species as a stem group within Mendacibombus.

\section{Lower Miocene}

\section{Subgenus Cullumanobombus Vogt, 1911}

\section{Bombus (Cullumanobombus) trophonius Prokop, Dehon, Michez \& Engel, 2017}

Holotype. Female. ZD0003 (coll. Bílina mine). Type specimen has been located and revised (Figs 2A, 3F).

Type strata and locality. Lower Miocene (i.e., 20.0 Ma), Clayey Superseam Horizon, Bílina mine, Czech Republic.

Diagnosis. The fossil has a wing pattern most similar to B. (Cullumanobombus) rufocinctus Cresson (Milliron 1973; Williams et al. 2014). Moreover, both species display a similar combination of $3 \mathrm{Rs}$ about as long as $\mathrm{r}$-rs but shorter than $4 \mathrm{Rs}$, a basal vein basad $1 \mathrm{cu}-\mathrm{a}$, a vein $2 \mathrm{Rs}$ arched posteriorly but not as greatly prolonged proximally as in several other species of Cullumanobombus (e.g., Milliron 1971), and a vein 1m-cu entering second submarginal cell near midpoint. However, the convex pterostigmal border within the marginal cell, less apically narrowed marginal cell, and less arched 2rs-m minimally serve to distinguish the fossil species from B. rufocinctus. See Prokop et al. (2003) and Prokop et al. (2017) for original diagnosis.

Description. Wings and integument black as preserved; forewing total length $14.6 \mathrm{~mm}$; maximum width $5.10 \mathrm{~mm}$; basal vein weakly arched basally, comparatively straight along length, basad cu-a by about vein width, in line with $1 \mathrm{Rs}$; M+Rs originating anteriad, 1 Rs slightly shorter than $\mathrm{r}$-rs; pterostigma short, slightly longer than wide, tapering inside of marginal cell, border inside marginal cell convex, prestigma nearly as long as pterostigma; marginal cell length $5.1 \mathrm{~mm}$, width $1.1 \mathrm{~mm}$, free portion slightly shorter than portion bordering submarginal cells, apex rounded and offset from anterior wing margin by much more than vein width, not appendiculate; 2Rs strongly arched basally and slightly arched outward; $r$-rs about as long as 3Rs; 4Rs slightly longer than 3Rs; three submarginal cells of approximately same sizes, albeit third slightly larger than first or second; first submarginal cell length $0.9 \mathrm{~mm}$ (as meas- 

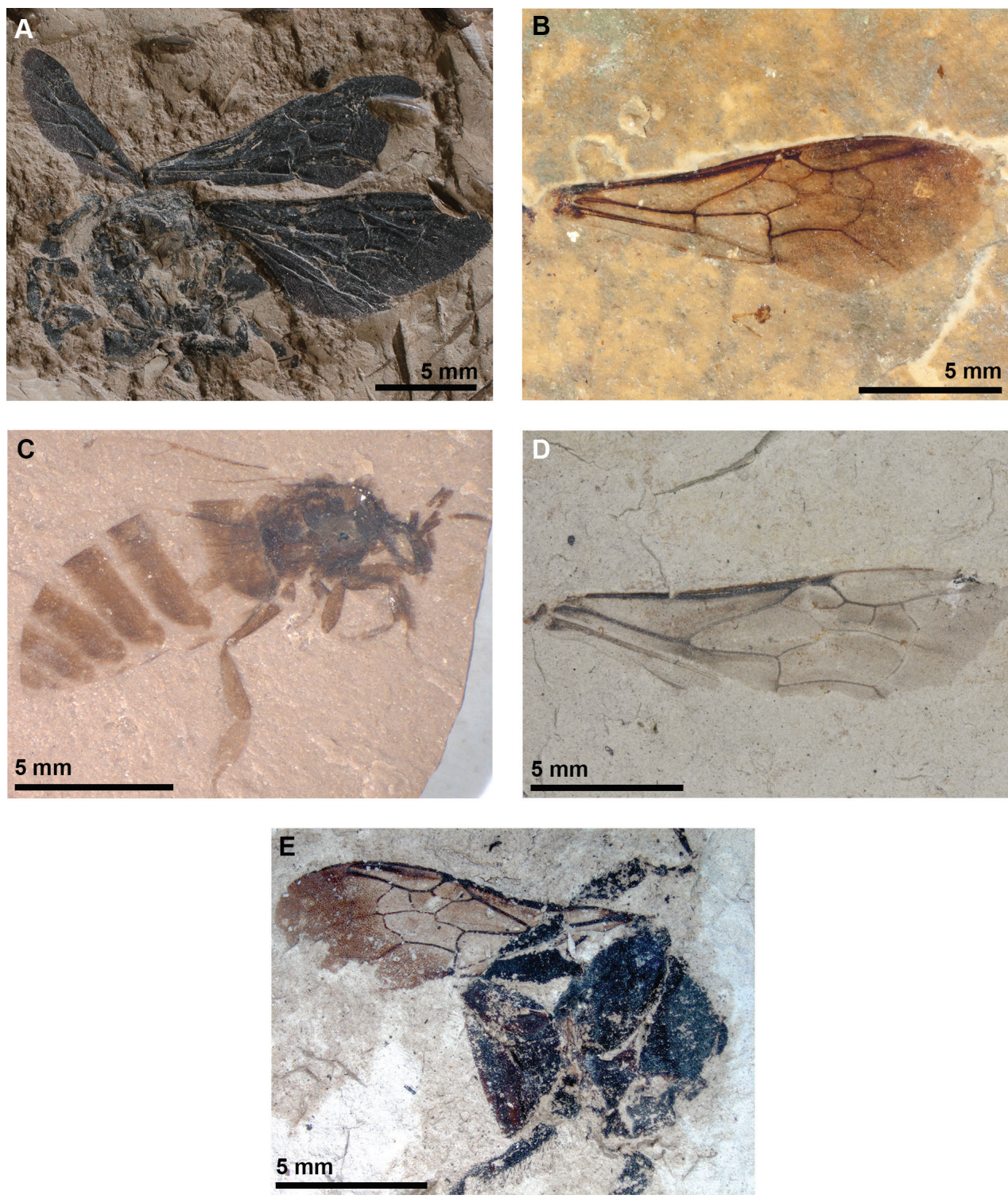

Figure 2. Representative fossil bumble bees $\mathbf{A}$ Bombus (Cullumanobombus) trophonius (photograph by Jakup Prokop) B B. (Cullumanobombus) randeckensis (photograph by Torsten Wappler) C B. vetustus (photograph by Alexandr P. Rasnitsyn) D B. (Cullumanobombus) pristinus (photograph by Irene Zorn and Monika Brüggeman-Ledolter) E B. (Melanobombus) cerdanyensis (photograph by Thibaut De Meulemeester).

ured from origin of $\mathrm{M}+\mathrm{Rs}$ to juncture of $\mathrm{r}-\mathrm{rs}$ and $\mathrm{Rs}$ ), width $1.0 \mathrm{~mm}$ (as measured from $\mathrm{Rs}+\mathrm{M}$ to pterostigma); second submarginal cell length $1.3 \mathrm{~mm}$ (as measured from juncture of Rs+M and $\mathrm{M}$ to juncture of Rs and 1rs-m), width $0.9 \mathrm{~mm}$ (as measured from midpoint on $\mathrm{M}$ between $1 \mathrm{~m}$-cu and $1 \mathrm{rs}-\mathrm{m}$ to juncture of $\mathrm{r}-\mathrm{rs}$ and $\mathrm{Rs}$ ); third submarginal cell length $1.6 \mathrm{~mm}$ (as measured from juncture of $1 \mathrm{rs}-\mathrm{m}$ and $\mathrm{M}$ to 
juncture of $\mathrm{M}$ and 2rs-m), width $1.2 \mathrm{~mm}$ (as measured from juncture of $\mathrm{M}$ and $2 \mathrm{~m}$-cu to juncture of 2rs-m and Rs); $1 \mathrm{rs}-\mathrm{m}$ straight; $2 \mathrm{rs}-\mathrm{m}$ arched distally in posterior half; $1 \mathrm{~m}$-cu distinctly angulate anteriorly near $\mathrm{M}$, entering second submarginal cell near cell's midlength; $2 \mathrm{~m}$-cu slightly arched apically, meeting third submarginal cell at cell's apical fifth of length. Hind wing length $9.4 \mathrm{~mm}$, width $2.6 \mathrm{~mm}$. Preserved portion of mesosoma and legs difficult to describe, although portion of metatibial corbicula preserved (basal quarter to third), and sclerites with numerous, long setae. See Prokop et al. (2003) and Prokop et al. (2017) for original description.

Comments. The specimen was first reported as Bombus sp. in Prokop et al. (2003). Prokop et al. (2017) demonstrated that the fossil clustered within contemporary Cullumanobombus and formally described the species. Although the majority of contemporary species of Cullumanobombus are found in the New World and a few species in the Old World, Hines (2008) estimated that the subgenus originated around 20.0-15.0 $\mathrm{Ma}$ in the Palearctic. Our result, as well as that of Prokop et al. (2017), is consistent with Hines (2008) as the fossil specimen was found in the Lower Miocene (i.e., 20.0 $\mathrm{Ma}$ ) deposits of Bílina Mine in northern Bohemia (Czech Republic).

\section{Bombus (Cullumanobombus) randeckensis Wappler and Engel in Wappler et al. (2012)}

Holotype. Sex unknown. The fossil consists of an isolated forewing. SMNS 68000/28 (old Armbruster collection No. A5119). Conserved in the Staatliches Museum für Naturkunde, Stuttgart, Germany. Type specimen has been located and revised (Figs 2B, 3G).

Type strata and locality. Randeck Maar, southeast of Stuttgart, Swabian Alb; Early Miocene, i.e., 16.0-18.0 Ma (Burdigalian, Karpatian, MN 5).

Diagnosis. Bombiform bee; infuscate area in marginal cell extends entire length of anterior half of marginal cell; forewing venation strictly similar to that of an extant bumble bee, with transector visible on both forewings. See Wappler et al. (2012) for original diagnosis.

Description. Forewing length $14.3 \mathrm{~mm}$, maximum width $5.0 \mathrm{~mm}$; marginal cell length $3.9 \mathrm{~mm}$; basal vein almost straight, slightly curved in its base, slightly basad cu-a; vein cu-a straight; three submarginal cells; first submarginal cell length $1.7 \mathrm{~mm}$ (as measured from origin of M+Rs to juncture of r-rs and Rs), width $0.8 \mathrm{~mm}$ (as measured from $\mathrm{M}+\mathrm{Rs}$ to pterostigma); second submarginal cell width $0.7 \mathrm{~mm}$ (as measured from midpoint on $\mathrm{M}$ between $1 \mathrm{~m}-\mathrm{cu}$ and $1 \mathrm{rs}-\mathrm{m}$ to juncture of $\mathrm{r}-\mathrm{rs}$ and $\mathrm{Rs}$ ); third submarginal cell length $1.3 \mathrm{~mm}$ (as measured from juncture of $1 \mathrm{rs}-\mathrm{m}$ and $\mathrm{M}$ to juncture of $\mathrm{M}$ and 2rs-m), width $1.1 \mathrm{~mm}$ (as measured from juncture of $\mathrm{M}$ and $2 \mathrm{~m}-\mathrm{cu}$ to juncture of 2rs-m and Rs); height of second medial cell $1.1 \mathrm{~mm}$ (as measured from Cu1 to juncture of $1 \mathrm{~m}$-cu and M); $1^{\text {st }}$ abscissa of Rs almost straight; $2^{\text {nd }}$ abscissa of Rs with anterior half curved apically; r-rs almost straight; $\mathrm{M}+\mathrm{Rs}$ straight and longer than $\mathrm{r}$-rs; 3Rs almost as long as r-rs; 4Rs slight smaller than $\mathrm{M}+\mathrm{R} s$; $1 \mathrm{rs}-\mathrm{m}$ almost straight; $2 \mathrm{rs}-\mathrm{m}$ with posterior half curved apically; $1 \mathrm{~m}$-cu curved apically in last anterior part, 
A

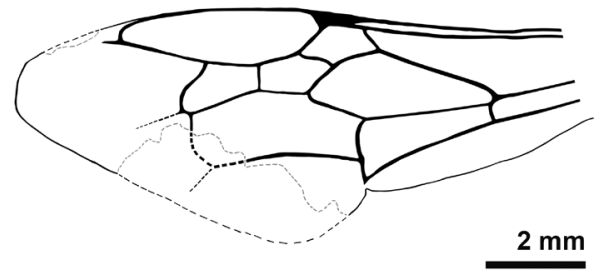

C

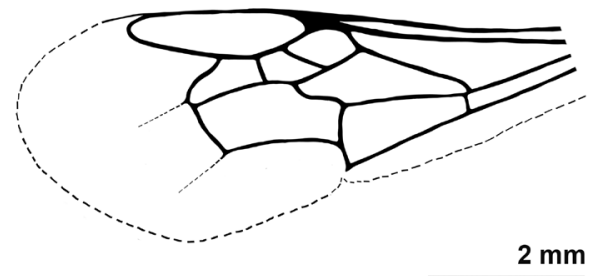

E

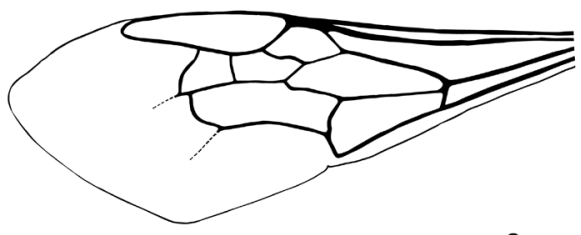

$2 \mathrm{~mm}$

G

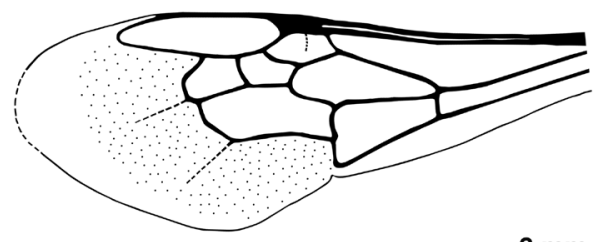

$2 \mathrm{~mm}$

I

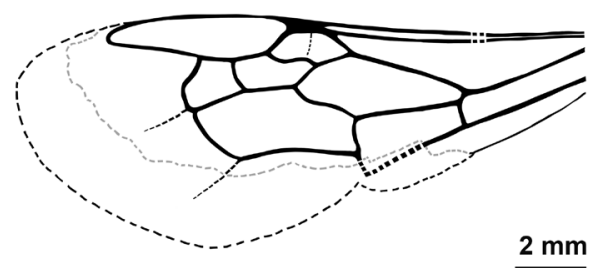

B

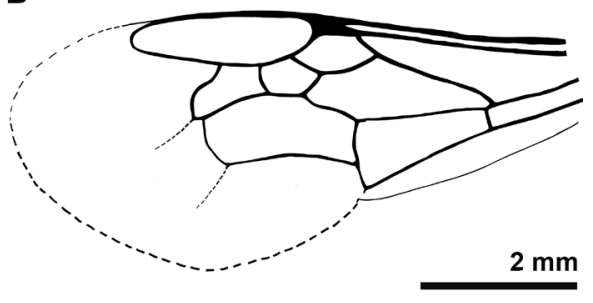

D

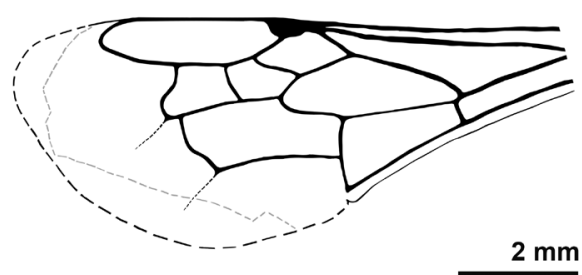

F

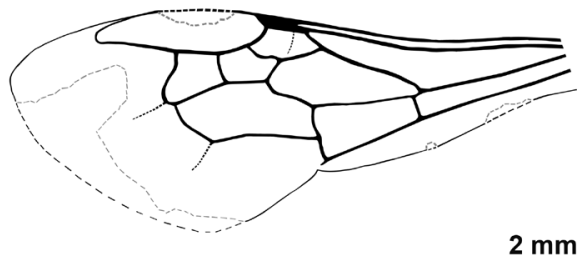

H

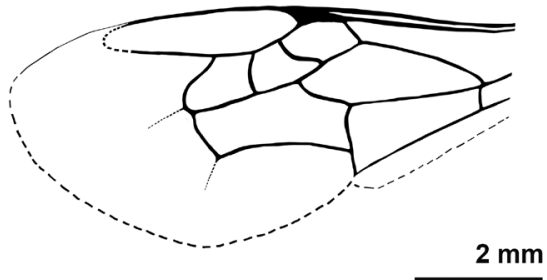

J

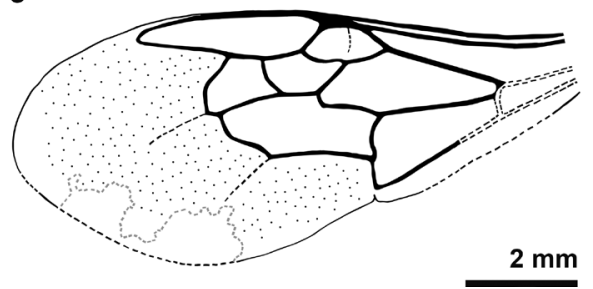

Figure 3. Forewing drawings of the fossil bumble bees studied herein. Some forewings were mirrored to enable comparison across all specimens A Oligobombus cuspidatus (mirrored) B Holotype of Calyptapis florissantensis (mirrored) C C. florissantensis D Bombus (Paraelectrobombus) patriciae (mirrored) E B. (Mendacibombus) beskonakensis $\mathbf{F}$ B. (Cullumanobombus) trophonius (mirrored) $\mathbf{G} B$. (Cullumanobombus) randeckensis (mirrored) $\mathbf{H}$ B. vetustus $\mathbf{I}$ B. (Cullumanobombus) pristinus (mirrored) $\mathbf{J}$ B. (Melanobombus) cerdanyensis. 
reaching second submarginal cell before midpoint; $2 \mathrm{~m}$-cu slightly curved, reaching $\mathrm{M}$ basad to 2rs-m. See Wappler et al. (2012) for original description.

Comments. The fossil was discovered in the Lower Miocene (i.e., 18.0-16.0 Ma) deposits of Randeck Maar, Germany, an age and locality in general accord with the estimate that Cullumanobombus originated between 20.0-15.0 Ma in the Old World. Based on the forewing shape affinities and the general morphological assessment, B. randeckensis is likely an extinct species of Cullumanobombus, like B. trophonius.

\section{Middle-Lower Miocene}

\section{“Bombus" luianus Zhang, 1990, species inquirenda}

Holotype. Female. Specimen n ${ }^{\circ}$ 82771. Plate XXXIII-1, fig. 164 from Zhang et al. (1994), plate I-1, 2 from Zhang (1990). The type material from Shanwang was not available for study and we have, therefore, had to base our information on this and the following two species (vide infra) on the original Chinese descriptions, the rather poor original photographs, and the tenuously accurate line drawings in these publications. Accordingly, our evaluation of $B$. luianus, $B$. dilectus, and $B$. anacolus has been considerably hampered.

Type strata and locality. Middle Miocene (i.e., 17.0-15.2 Ma), deposit of the Shanwang Formation, large lacustrine and lithified deposit, with diatomaceous and tuffaceous mudstone. Located in Linqu County, Shanwang Province, China.

Description. Taken from Zhang (1990) and Zhang et al. (1994): Prosoma poorly preserved; meso- and metasoma preserved; mesosoma stout, setose, and dark; metasoma dark, reddish-brown near apex, displaying five segments, suboval in shape, little longer than wide, distinctly narrower than mesosoma; forewing membrane brown and transparent, venation dark brown; metatibia widening posteriorly, displaying two strong spurs, outer margin covered with strong coarse setae; metabasitarsus flat, rectangular, truncated at both ends, nearly as wide as distal part of metatibia; tarsomere IV displaying pair of spur-like bristles distally; inner margin of pretarsal claw displaying single tooth at midlength; forewing length approximately $14.0 \mathrm{~mm}$, maximum width approximately $4.5 \mathrm{~mm}$ as preserved; basal vein relatively straight and almost in line with cu-a; cu-a almost straight; $1^{\text {st }}$ abscissa of Rs straight; $2^{\text {nd }}$ abscissa of Rs curved anteriorly; r-rs curved; Rs+M straight and shorter than r-rs; 3Rs almost straight and as long as r-rs; 4 Rs almost straight and longer than r-rs; marginal cell length approximately $4.0 \mathrm{~mm}$, width $0.8 \mathrm{~mm}$; three submarginal cells; $1 \mathrm{rs}-\mathrm{m}$ slightly curved apically near midpoint; $2 \mathrm{rs}-\mathrm{m}$ curved apically in its posterior half; $1 \mathrm{~m}$-cu almost straight and reaching $\mathrm{M}$ near midpoint between $2^{\text {nd }}$ abscissa of Rs and $1 \mathrm{rs}-\mathrm{m} ; 2 \mathrm{~m}$-cu slightly curved and reaching $\mathrm{M}$ basad to $2 \mathrm{rs}-\mathrm{m}$; hind wing length $8.6 \mathrm{~mm}$; total body length approximately $13.0 \mathrm{~mm}$, width approximately $8.0 \mathrm{~mm}$ as preserved. The original description and figure do not display a transector vein. See Zhang (1990) and Zhang et al. (1994) for original descriptions. 


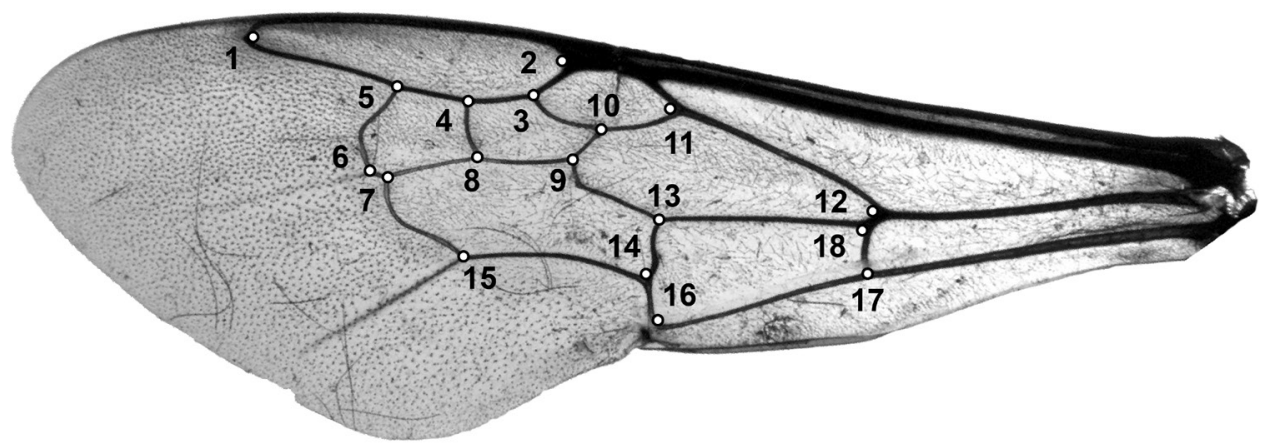

Figure 4. Left forewing of Bombus (Bombus) terrestris (Linnaeus, 1758) with the 18 landmark points indicated on the veins to describe the shape (photograph by Michaël Terzo). The names of the veins and cells can be found in Dehon et al. (2017).

Comments. According to Zhang (1990), the fossil species is closely similar to B. (Bombus) tunicatus Smith, 1852 (extant species distributed in Himalaya), but differs from it in that the mesosoma is narrower than the mesosoma, and not so massive as is usual for the genus; the spurs becoming shorter; vein $1 \mathrm{~m}$-cu meeting second submarginal cell at midlength; and veins $\mathrm{M}+\mathrm{Cu}$ and $\mathrm{M}$ of hind wing aligned in a straight line. The validity of these features for distinguishing the species remains unclear. Our morphometric study showed a similar shape with the subgenus Melanobombus. It is estimated that Melanobombus originated between the Lower and Middle Miocene, while the fossil was discovered in the Middle Lower Miocene (i.e., 17.0-15.2 Ma) deposits of Shandong, China (Zhang 1990; Zhang et al. 1994). The results based on geometric morphometric analyses for this species could be wrong, since they were based on Zhang's drawings and not on a picture or on examination of the holotype. Given this, we consider the fossil as species inquirenda.

\section{“Bombus" dilectus Zhang, 1994, species inquirenda}

Holotype. Female. Plate XXXIII-3, figs 168, 169 from Zhang et al. (1994). We were not able study the holotype (see comment under $B$. luianus, vide supra).

Type strata and locality. Middle Miocene (i.e., 17.0-15.2 Ma), deposit of the Shanwang Formation, large lacustrine and lithified deposit, with diatomaceous and tuffaceous mudstone. Located in Linqu County, Shanwang Province, China.

Description. Taken from Zhang et al. (1994): Forewing and hind wing membrane papillate distally; forewing membrane dark brown; forewing length more than 15.0 $\mathrm{mm}$, maximum width more than $6.0 \mathrm{~mm}$ as preserved; basal vein slightly curved, basad cu-a; cu-a very slightly curved apically; marginal cell length approximately 5.0 $\mathrm{mm} ; 1^{\text {st }}$ abscissa of Rs slightly curved apically near midpoint; $2^{\text {nd }}$ abscissa of Rs curved apically near midpoint; $\mathrm{r}-\mathrm{rs}$ straight; Rs+M straight and longer than r-rs; 3Rs straight and smaller than $\mathrm{r}$-rs; 4Rs almost as long as Rs+M; three submarginal cells; $1 \mathrm{rs-m}$ 


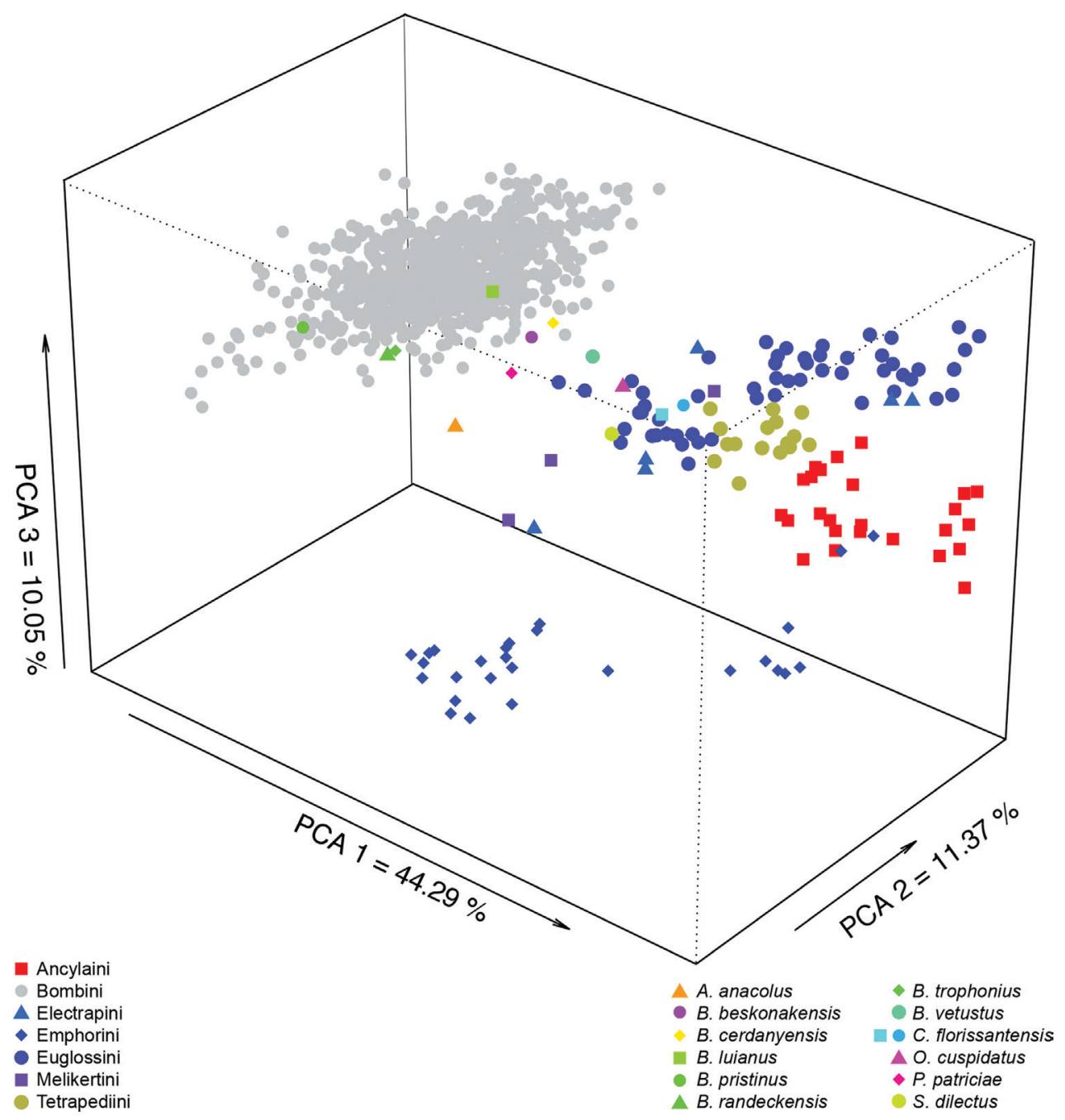

Figure 5. Ordination of the fossils along the three first axes of the PCA (PC1 $=44.29 \%, \mathrm{PC} 2=11.37 \%$, PCA3 $=10.05 \%)$ in subgeneric dataset of Bombus s. 1 .

straight; $2 \mathrm{rs}-\mathrm{m}$ curved apically in its posterior half; $1 \mathrm{~m}$-cu straight, reaching $\mathrm{M}$ near midpoint between $2^{\text {nd }}$ abscissa of Rs and $1 \mathrm{rs}-\mathrm{m} ; 2 \mathrm{rs}-\mathrm{m}$ curved and reaching $\mathrm{M}$ basad to $2 \mathrm{rs}-\mathrm{m}$; total body length approximately less than $20.0 \mathrm{~mm}$ as preserved. The original description and figure do not display a transector vein. See Zhang et al. (1994) for original description.

Comments. The specimen was first described as B. dilectus by Zhang et al. (1994) and was stated to be similar to $B$. anacolus in that the wing color of both fossil species is rather dark and not transparent, or at most semi-transparent at the wing margins, a character differing from that of living species. However, some extant species display fairly dark wings (e.g., B. (Melanobombus) simillimus Smith, 1852). The authors also stated that the wings and body color of $B$. dilectus are darker than $B$. anacolus. As ob- 
served for B. luianus, results based on geometric morphometric analyses for this species (i.e., similarity to subgenus Bombus) could be wrong, since it was based on Zhang's drawings. Given this, we consider this fossil as species inquirenda.

\section{"Bombus" anacolus Zhang, 1994, species inquirenda}

Holotype. Female. Plate XXXIII-2, figs 165, 166, 167 in Zhang et al. (1994). We were not able study the holotype (see comment under B. luianus, vide supra).

Type strata and locality. Middle Miocence (i.e., 17.0-15.2 Ma), deposit of the Shanwang Formation, large lacustrine and lithified deposit, with diatomaceous and tuffaceous mudstone. Located in Linqu County, Shanwang Province, China.

Description. Taken from Zhang et al. (1994): Forewing blackish brown, opaque; forewing and hind wing papillate distally; forewing length approximately $15.0 \mathrm{~mm}$, maximum width approximately $6.00 \mathrm{~mm}$ as preserved; basal vein relatively straight and basad cu-a; cu-a almost straight; marginal cell length almost $5.0 \mathrm{~mm}$, width 1.1 $\mathrm{mm} ; 1^{\text {st }}$ abscissa of Rs almost straight; $2^{\text {nd }}$ abscissa of Rs slightly curved near midpoint; r-rs straight; Rs+M straight and longer than r-rs; 3Rs straight and smaller than r-rs; 4Rs straight and approximately as long as Rs+M; three submarginal cells, second smallest; 1 rs-m straight; 2 rs-m curved apically in its posterior half; $1 \mathrm{~m}$-cu relatively straight, reaching $M$ near midpoint between $2^{\text {nd }}$ abscissa of Rs and $1 \mathrm{rs}-\mathrm{m} ; 2 \mathrm{~m}$-cu curved apically, reaching $\mathrm{M}$ basad to $2 \mathrm{rs}-\mathrm{m}$; total body length approximately $13.0 \mathrm{~mm}$ as preserved (large part of metasoma missing). See Zhang et al. (1994) for original description.

Comments. The specimen was described as B. anacolus by Zhang et al. (1994), and considered to be close to B. luianus, a species collected from the same deposit. Based on geometric morphometric analyses this species is similar to Mendacibombus, and it could be a relative of this subgenus. This hypothesis is supported by the fact that Mendacibombus is estimated to have originated around the Eocene-Oligocene boundary (i.e., $34 \mathrm{Ma}$ ) in the Old World (Hines 2008), while the fossil was discovered in the Middle Lower Miocene (i.e., 17.0-15.2 Ma) deposit of Shandong in China (Zhang 1990; Zhang et al. 1994). Moreover, the crown age of extant members of Mendacibombus apparently diversified during the Late Miocene (i.e., $8 \mathrm{Ma}$ ). As observed for $B$. luianus and $B$. dilectus, results based on geometric morphometric analyses for this species could be wrong since it was based on Zhang's drawings. Given this, we consider the fossil as species inquirenda.

\section{Upper Miocene}

\section{“Bombus” vetustus Rasnitsyn \& Michener, 1991, species inquirenda}

Holotype. Male. \#2054/229, part and counterpart impressions of an entire male, deposited in the Palaeontological Institute, Russian Academy of Science, Moscow. Type specimen was located and revised (Figs 2C, 3H). 
Type strata and locality. Upper Miocene (i.e., 11.2-7.1 Ma), Botchi Formation, located on the left bank of the Botchi River, Russia.

Description. Male: Forewing length $10.4 \mathrm{~mm}$ as preserved; basal vein long and slightly basad cu-a; cu-a straight; marginal cell length approximately $3.3 \mathrm{~mm}$, width approximately $0.7 \mathrm{~mm}$ as preserved; $1^{\text {st }}$ abscissa of Rs straight; $2^{\text {nd }}$ abscissa of Rs relatively straight; $\mathrm{r}$-rs almost straight; Rs+M slightly curved and slightly longer than r-rs; 3Rs smaller than $\mathrm{r}-\mathrm{rs}$; 4 Rs slightly longer than $\mathrm{Rs}+\mathrm{M}$; three submarginal cells; first submarginal cell length $1.3 \mathrm{~mm}$ (as measured from origin of Rs+M to juncture of $\mathrm{r}$-rs and Rs), width $0.6 \mathrm{~mm}$ (as measured from $\mathrm{Rs}+\mathrm{M}$ to pterostigma); second submarginal cell length $1.1 \mathrm{~mm}$ (as measured from juncture of Rs+M and $\mathrm{M}$ to juncture of Rs and $1 \mathrm{rs}-\mathrm{m}$ ), width $0.6 \mathrm{~mm}$ (as measured from midpoint on $\mathrm{M}$ between $1 \mathrm{~m}-\mathrm{cu}$ and $1 \mathrm{rs}-\mathrm{m}$ to juncture of $\mathrm{r}$-rs and Rs); third submarginal cell length $1.2 \mathrm{~mm}$ (as measured from juncture of $1 \mathrm{rs}-\mathrm{m}$ and $\mathrm{M}$ to juncture of $\mathrm{M}$ and $2 \mathrm{rs}-\mathrm{m}$ ), width $0.9 \mathrm{~mm}$ (as measured from juncture of $\mathrm{M}$ and $2 \mathrm{~m}$-cu to juncture of $2 \mathrm{rs}-\mathrm{m}$ and $\mathrm{Rs}$ ); $2 \mathrm{rs}-\mathrm{m}$ with posterior half curved apically, $1 \mathrm{~m}$-cu reaching $\mathrm{M}$ near midpoint; $2 \mathrm{~m}$-cu curved and reaching $\mathrm{M}$ basad to 2rs-m; prosoma length $3.9 \mathrm{~mm}$; profemur length $1.9 \mathrm{~mm}$; protibial length $1.8 \mathrm{~mm}$; basitarsus length $1.6 \mathrm{~mm}$; setae of pro- and mesosoma dark; total body length $19.2 \mathrm{~mm}$ as preserved. See Rasnitsyn and Michener (1991) for original description.

Comments. Given that this is a male specimen, further work is needed with comparisons of its forewing shape with a diverse dataset based on males. In addition, the venation is incompletely preserved and so hopefully further and more complete material will be discovered.

\section{Subgenus Cullumanobombus Vogt, 1911}

\section{Bombus (Cullumanobombus) pristinus Unger, 1867}

Holotype. Inventory number GBA 1867/004/0004. Sex unknown. The holotype is currently deposited in the Geologische Bundesanstalt (Vienna, Austria). Type specimen has been located and revised (Figs 2D, 3I).

Type strata and locality. Upper Miocene (i.e., 11.2-7.1 Ma), Kumi deposit, Euboea Island (Euboea, Greece).

Diagnosis. Basal vein long and almost straight, basad to apically curved cu-a; pterostigma slightly longer than prestigma: second abscissa of Rs with anterior half curved apically; three submarginal cells of approximately same size; $1 \mathrm{rs}-\mathrm{m}$ almost straight; $2 \mathrm{rs}-\mathrm{m}$ posterior half curved apically; $1 \mathrm{~m}$-cu with anterior half curved apically, reaching second submarginal cell slightly before midpoint; $2 \mathrm{~m}$-cu very slightly curved, reaching M basad to 2rs-m.

Description. Forewing length approximately $16.0 \mathrm{~mm}$, maximum width $4.3 \mathrm{~mm}$ as preserved; forewing membrane hyaline, venation black becoming grey when reaching apex of forewing; marginal cell length $4.9 \mathrm{~mm}$, width $1.2 \mathrm{~mm}$; basal vein long and almost straight, basad cu-a; vein cu-a curved apically; pterostigma slightly longer than 
prestigma; three submarginal cells; first submarginal cell length $2.1 \mathrm{~mm}$ (as measured from origin of Rs+M to juncture of $\mathrm{r}-\mathrm{rs}$ and Rs), width $0.9 \mathrm{~mm}$ (as measured from $\mathrm{Rs}+\mathrm{M}$ to pterostigma); second submarginal cell length $2.2 \mathrm{~mm}$ (as measured from juncture of Rs+M and $\mathrm{M}$ to juncture of Rs and $1 \mathrm{rs}-\mathrm{m}$ ), width $0.9 \mathrm{~mm}$ (as measured from midpoint on $\mathrm{M}$ between $1 \mathrm{~m}-\mathrm{cu}$ and $1 \mathrm{rs}-\mathrm{m}$ to juncture of $\mathrm{r}-\mathrm{rs}$ and Rs); third submarginal cell length $1.6 \mathrm{~mm}$ (as measured from juncture of $1 \mathrm{rs}-\mathrm{m}$ and $\mathrm{M}$ to juncture of $\mathrm{M}$ and $2 \mathrm{rs}-\mathrm{m}$ ), width $1.3 \mathrm{~mm}$ (as measured from juncture of $\mathrm{M}$ and $2 \mathrm{~m}$-cu to juncture of 2rs-m and Rs); second abscissa of Rs with anterior half curved apically; $1 \mathrm{rs}-\mathrm{m}$ almost straight; 2 rs-m posterior half curved apically; $1 \mathrm{~m}-\mathrm{cu}$ with anterior half curved apically, reaching second submarginal cell slightly before midpoint; $2 \mathrm{~m}$-cu very slightly curved, reaching $M$ basad to $2 \mathrm{rs}-\mathrm{m}$. It seems that a transector vein is visible on the first submarginal cell, but it might be an artefact created by the taphonomic alteration of the specimen. See Unger (1867) for original description.

Comments. The type of $B$. pristinus consists of just one right forewing. The specimen was described and illustrated by Unger (1867). The illustration, displaying a left forewing, is reversed left to right. Unger attributed the species to Regenhofer but, according to Rasnitsyn and Michener (1991), the latter appears not to have written the comments or prepared the illustration of Unger's work, thus making them conclude that the name must be attributed to Unger. Based on morphological and geometric morphometric analyses, it is likely that this fossil is an extinct species of Cullumanobombus.

\section{Subgenus Melanobombus Dalla Torre, 1880}

\section{Bombus (Melanobombus) cerdanyensis Dehon, De Meulemeester \& Engel, 2014}

Holotype. Sex unknown. Conserved in the Paleontology department collection, Muséum national d'Histoire naturelle, Paris, France. The fossil consists of a part and counterpart. Type specimen has been located and revised (Figs 2E, 3I).

Type strata and locality. Late Miocene (i.e., 10.0 Ma), lacustrine beds of Cerdanya, Spain.

Diagnosis. Forewing membrane with alar papillae beyond apical crossveins; membrane infuscate, particularly in area beyond apical crossveins and along anterior borders of radial and marginal cells; pterostigma small, trapezoidal, not larger relative to prestigma and width not much shorter than length; marginal cell longer than distance from apex to forewing tip, tapering in width across its length, with apex acutely rounded and slightly offset from forewing margin; three submarginal cells of approximately same size, anterior borders of second and third submarginal cells subequal; $1 \mathrm{~m}-\mathrm{cu}$ angulate anteriorly, meeting second submarginal cell near midpoint; $2 \mathrm{~m}$-cu slightly arched, meeting third submarginal cell in apical fifth; mesotibia five times longer than wide; transector vein visible in the first submarginal cell. See Dehon et al. (2014) for original diagnosis.

Description. Fossil compressed in apparently dorsal oblique view, with left forewing outstretched; right forewing not preserved; hind wings not preserved; prosoma 


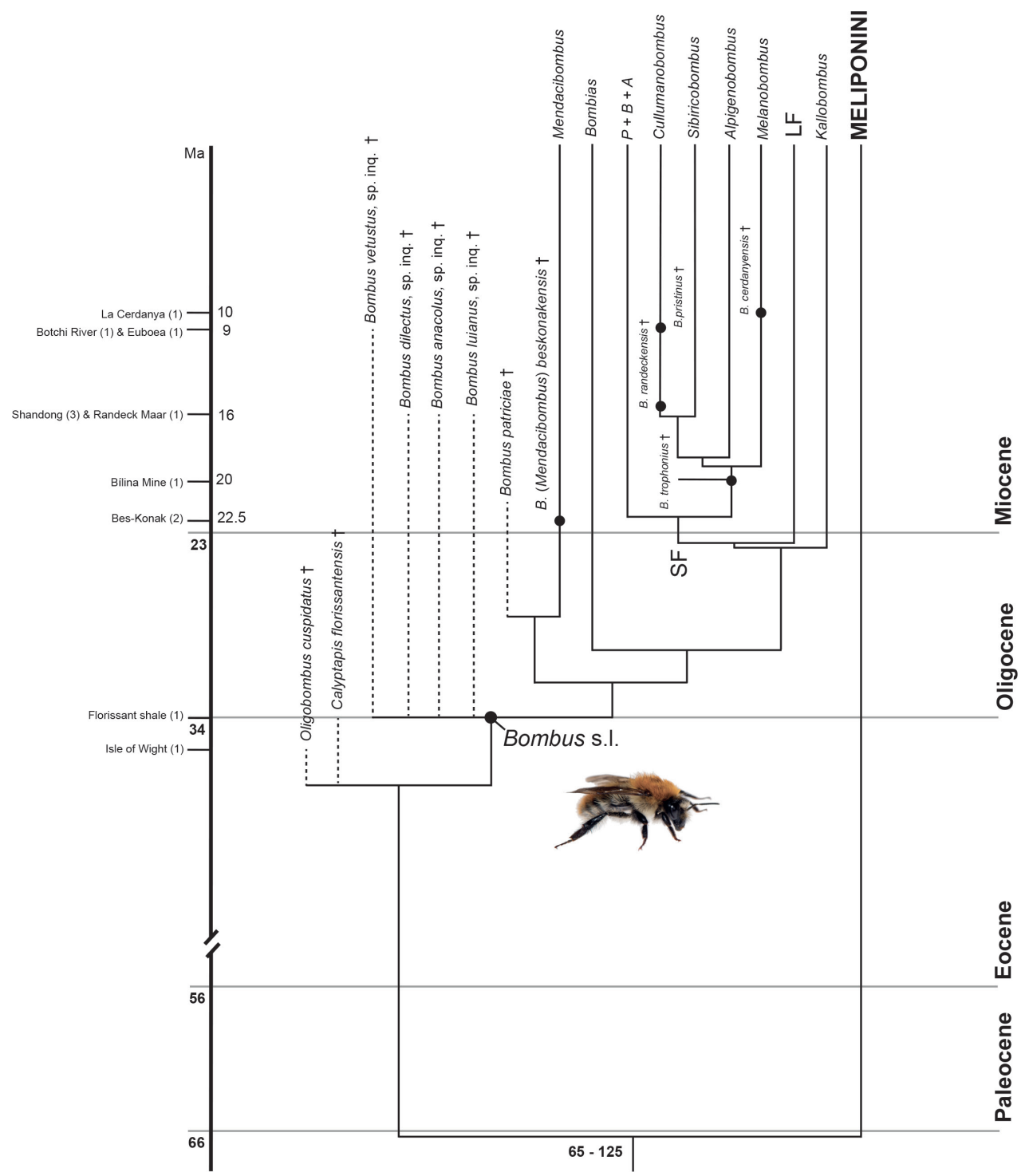

Figure 6. Hypothesis of bumble bee evolution according to the branching dates of Hines (2008) alone with the subgeneric system of Williams et al. (2008). Fossils are mapped onto the clade according to our hypotheses based on our wing morphometry/shape results. Geometric morphometric analyses should be considered as a heuristic tool given the absence of other forms of pertinent data (e.g., absence of information on mandibular form, pretarsal structure, genitalic characters, etc.). $\mathrm{A}=$ Alpinobombus. $\mathrm{B}=$ Bombus s.str. $\mathrm{LF}=$ clade with mostly long-faced species. $\mathrm{P}=$ Pyrobombus $. \mathrm{SF}=$ clade with mostly short-faced species .

not preserved; mesosoma and metasoma incomplete and damaged; mid and hind legs preserved, partially overlapping forewing; right profemur length $1.4 \mathrm{~m}$, width $0.8 \mathrm{~mm}$ as preserved; left mesofemur length $3.6 \mathrm{~mm}$, width $0.9 \mathrm{~mm}$; mesotibia length $3.0 \mathrm{~mm}$, width $0.6 \mathrm{~mm}$; mesobasitarsus length $3.2 \mathrm{~mm}$, width $0.9 \mathrm{~mm}$; remaining tarsomeres 
and pretarsal claws well preserved; pretarsal claws apparently not toothed as preserved; right mesofemur length $3.5 \mathrm{~mm}$, width $0.5 \mathrm{~mm}$; mesotibia length $2.0 \mathrm{~mm}$, width $0.4 \mathrm{~mm}$ as preserved; left forewing length $13.3 \mathrm{~mm}$, maximum width $4.6 \mathrm{~mm}$; three submarginal cells of similar size; first submarginal cell length $1.5 \mathrm{~mm}$ (as measured from origin of Rs+M to juncture of $\mathrm{r}-\mathrm{rs}$ and $\mathrm{Rs}$ ), heigth $0.7 \mathrm{~mm}$ (as measured from Rs+M to pterostigma); second submarginal cell length $1.5 \mathrm{~mm}$ (as measured from juncture of Rs+M and $\mathrm{M}$ to juncture of Rs and $1 \mathrm{rs}-\mathrm{m}$ ), height $0.8 \mathrm{~mm}$ (as measured from midpoint on $\mathrm{M}$ between $1 \mathrm{~m}-\mathrm{cu}$ and $1 \mathrm{rs}-\mathrm{m}$ to juncture of $\mathrm{r}-\mathrm{rs}$ and Rs); third submarginal cell length $1.3 \mathrm{~mm}$ (as measured from juncture of $1 \mathrm{rs}-\mathrm{m}$ and $M$ to juncture of $M$ and 2rs-m), height $1.1 \mathrm{~mm}$ (as measured from juncture of $\mathrm{M}$ and $2 \mathrm{~m}$-cu to juncture of $2 \mathrm{rs}-$ $\mathrm{m}$ and $\mathrm{Rs}$ ); first medial cell length $3.4 \mathrm{~mm}$ (as measured from juncture of $\mathrm{M}+\mathrm{Cu}$ and $\mathrm{Cu}$ to juncture of $1 \mathrm{~m}-\mathrm{cu}$ and $\mathrm{M}$ ), height $1.2 \mathrm{~mm}$ (as measured from juncture of $\mathrm{M}$ and $\mathrm{Rs}+\mathrm{M}$ to midpoint on $\mathrm{Cu}$ between $\mathrm{M}+\mathrm{Cu}$ and $1 \mathrm{~m}-\mathrm{cu}$ ); pterostigma length $0.9 \mathrm{~mm}$; marginal cell length $3.4 \mathrm{~mm}$ with apex rounded, offset from anterior wing margin, not appendiculate; $1 \mathrm{~m}$-cu strongly curved, meeting second submarginal cell near midpoint; $2 \mathrm{~m}-\mathrm{cu}$ slightly arched, meeting third submarginal cell in apical fifth; metasoma width $5.8 \mathrm{~mm}$ as preserved; first two segments visible, first segment length $1.8 \mathrm{~mm}$, second segment length $1.2 \mathrm{~mm}$ as preserved. See Dehon et al. (2014) for original description.

Comments. The attribution based on geometric morphometric analysis (i.e., Melanobombus) is consistent with the timing and geographic origin of the subgenus proposed by Hines (2008). Indeed, the fossil was found in the Upper Miocene (i.e., 10.0 Ma) deposit of La Cerdanya in Spain, while Melanobombus is estimated to have originated between 20.0-15.0 Ma in the Old World. The relative sizes of the prestigma and pterostigma exclude a placement in the Electrobombini (although the presence or absence of a jugal lobe in the hind wing cannot be determined in the holotype). The forewing is apically papillate (as in Bombini), and the marginal cell is not appendiculate and $1 \mathrm{~m}-\mathrm{cu}$ is strongly angulate together suggesting the species does not belong to the Electrapini or Melikertini (although some melikertines have $1 \mathrm{~m}$-cu more angulate, such as Melissites trigona Engel, $1 \mathrm{~m}-\mathrm{cu}$ is always much shorter and not as long as in Bombini or Euglossini; a long $1 \mathrm{~m}$-cu is more plesiomorphic among Corbiculata). Indeed, the forewings of the present fossil are distinctly Bombus-like: presence of papillae, general infuscation of the membrane, three submarginal cells of relatively similar size (albeit the latter character is assuredly plesiomorphic). Based on the specimen morphology and forewing shape affinities, the fossil is likely an extinct species of Melanobombus.

\section{Discussion}

\section{Geometric morphometrics of forewing shape to discriminate taxa}

As shown in Michez et al. (2009b), De Meulemeester et al. (2012), Wappler et al. (2012), Dehon et al. (2014, 2017), Dewulf et al. (2014), and Prokop et al. (2017), geometric morphometric analyses of forewing shape provide a robust tool for assessing the taxo- 
nomic affinities of bee fossils with contemporary taxa and insights into bee evolution. We additionally demonstrate herein that the Hit Ratios for subgeneric level assessments were high for the genus Bombus. However, we need to combine geometric morphometrics of forewing shape with morphological features (e.g., pilosity, leg morphology, head and mouthpart characters, etc.) to get more powerful results, but such morphological characters are either limited or lacking with the current impression fossils.

\section{Taxonomic affinities of Calyptapis florissantensis and Oligobombus cuspidatus}

When using the first dataset with tribe a priori grouping, the most similar tribe to $C$. florissantensis (i.e., both specimens) and O. cuspidatus is Electrapini, while Tetrapediini is the second most similar tribe to $C$. florissantensis and Tetrapediini is the second most similar tribe to O. cuspidatus (LDA 3; Suppl material 10: Table S10). When using the second dataset, the most similar tribe to the holotype of $C$. florissantensis is Bombini, while the most similar tribe to the specimen described by Cockerell (1908) is Electrapini (the second most similar tribe being Bombini). The most similar tribe to $O$. cuspidatus is Bombini when using the second dataset (LDA 4; Suppl material 12: Table S12). Those results might be explained by the fact that when using the first dataset, only 20 specimens (i.e., four species, with five specimens per species) were chosen to represent Bombini, compared to 841 specimens (i.e., 210 species) in the second dataset and thereby more fully encompasses the breadth of morphospace represented among modern bombines. Furthermore, the species used to represent Bombini in the first dataset do not represent early-branching subgenera, which were found to be the most similar subgenera to $C$. florissantensis and O. cuspidatus in the third dataset (i.e., Bombias) (LDA 5; Suppl material 13: Table S13). The similarity of O. cuspidatus with Electrapini when using the first dataset is concordant with Antropov et al. (2014), who considered it as a possible member of Bombini with mixed features of Bombini and other corbiculate tribes (i.e., the extinct Electrapini, Electrobombini, Melikertini, and the extant Euglossini). This fossil may represent an extinct stem-group to Bombini and it would explain the different results obtained with the different datasets; those similarities across Bombini and the other tribes representing symplesiomorphic features encompassing the clade. Based on morphological features (i.e., presence of a corbicula, the forewing venation similar to Bombus s. 1.) and forewing shape similarities, C. florissantensis could also belong to a stem-group bombine (Cockerell 1906, 1908; Zeuner and Manning 1976). Based on the available evidence, the conservative position is to consider both species as possible stem-group Bombini. It would be highly desirable to verify this hypothesis using cladistic analyses of new morphological characters in the future.

\section{Origin and diversification of bumble bees}

Our results generally support the timing of divergence of extant species proposed by Williams (1985) and Hines (2008) (Fig. 5), noting that the meager record available for 
Bombini means such corroboration is minimal at best, albeit non-contradictory. The record of fossil bumble bees is sufficiently scant that at its best we can conclude that the available record does not contradict prior estimates, and falls in line with those for the subgenera Cullumanobombus, Melanobombus, and Mendacibombus. Unfortunately, fossils of most lineages within Bombus and certainly from more numerous and refined slices of time are simple lacking, meaning that the current record of fossil bumble bees lacks resolution for determining the timing of most diversification events (e.g., most fossils are clustered within a few deposits representing widely disparate slices in the Oligocene and Miocene). Nonetheless, none of the specimens from Eocene and Oligocene deposits were assigned within the shape space of any contemporary subgenus of Bombus, which is not surprising when looking at more completely preserved bees from, for example, the Eocene amber deposits (Baltic, Cambay, Rovno) (e.g., Engel 2001). On the other hand, most specimens coming from Miocene deposits were assigned within the contemporary shape space of Bombus s. l., and for some of them within contemporary subgenera (i.e., Cullumanobombus, Melanobombus, and Mendacibombus), again a pattern consistent with more completely preserved bees from other Miocene deposits (e.g., Dominican, Mexican amber) (e.g., Engel et al. 2012). This pattern mirrors the hypothesis that there were significant changes in the bee fauna between Eocene and Oligocene epochs and again at the Paleogene-Neogene transition (e.g., Engel 2001, 2004, 2019a, b). Contemporary species of Melanobombus and Mendacibombus are restricted to the Old World. On the other hand, most species of Cullumanobombus (excluding B. cullumanus, B. semenoviellus, B. unicus) occur in the New World (Williams 1998; Williams et al. 2014). Cullumanobombus and Melanobombus are estimated to have originated between 20.0-15.0 Ma, while the basal subgenus Mendacibombus has been estimated to have originated around 34.0-30.0 Ma (Hines 2008). All fossils having affinities to extant subgenera have an age that is posterior to the stem age of subgenera (Hines 2008), and therefore our assignments are coincident with the estimated origin and divergence times of Bombus s. 1. and extant subgenera (Hines 2008).

Other fossil specimens that were assigned to extant subgenera of Bombus s. 1. are in accordance with the estimated stem age of those groups. In occurrence, our analyses are concordant with the ages of Cullumanobombus and Melanobombus (i.e., between 20.00-15.00 Ma), as well as Mendacibombus (i.e., between 34.0-30.0 Ma) (Hines 2008). These species highlight that Bombini had diversified significantly by the Miocene and that these limited fossil data are concordant with dating estimates. Continued paleontological exploration will only further refine our understanding based on direct evidence for dating bumble bee evolution.

\section{Cenozoic extinctions of Corbiculata}

Corbiculata are the most represented bees in the fossil record, especially in terms of number of specimens found in amber deposits, with workers of certain stingless bees (Meliponini) numbering into the tens of thousands of individuals (Michez et al. 2012; Engel and Michener 2013b; Engel pers. obs.). Corbiculata appeared in the Late Cre- 
taceous based on the occurrence of a crown-group meliponine in Maastrichtian-aged Raritan amber (Michener and Grimaldi 1988; Engel 2000). This indicates that the divergence events among the tribes, at least among their stem groups, extend back to at least the latest Cretaceous. The three extinct tribes of corbiculate bees Electrapini, Electrobombini, and Melikertini are known from the Eocene (Baltic amber, Cambay amber, various impression fossil deposits such as Messel and Eckfeld), and some of these were assuredly advanced eusocial like Apini and Meliponini based on the presence of morphologically specialized workers (Engel 2001). Dehon et al. (2014) described a new corbiculate species, Euglossopteryx biesmeijeri De Meulemeester, Michez \& Engel, 2014 discovered in the Parachute Creek Member of the Green River Formation (Utah, USA), and had phenetic similarities in wing shape to Euglossini, but it remains to be determined whether this was symplesiomorphic similarity or indicative of a cladistic relationship.

During the Paleocene-Eocene (the Paleocene-Eocene Thermal Maximum and Eocene Thermal Optimum), the concentration of greenhouse gases and the mean global temperature was higher than at present, with poles with little to no ice (Zachos et al. 2001; Royer 2006). The Early Eocene was marked by the EECO (Early Eocene Climatic Optimum) 51-53 million years ago, with a high $\mathrm{pCO}_{2}$ and the global temperature reaching a long-term maximum. This was likely caused in part by differences in volcanic emissions, particularly high during parts of the Paleocene-Eocene periods (i.e., 40.0-60.0 Ma) (Walker et al. 1981). The PETM (Paleocene Eocene Thermal Maximum, i.e., $55.0 \mathrm{Ma}$ ) is the most prominent and best-studied hyperthermal episode, during which the global temperature increased by more than $5^{\circ} \mathrm{C}$ in less than 10,000 years (Zachos et al. 2001, 2008). A global cooling that most certainly caused the large-scale extinction of many plant and animal species marked the Eocene-Oligocene transition (i.e., 34.0 Ma) (Zachos et al. 2008; Hansen et al. 2013). Although still speculative at this time, it could be hypothesized that the latter event was related to the extinction of the group of Bombini to which Calyptapis florissantensis and Oligobombus cuspidatus might have belonged. Similarly, Dehon et al. (2014) suggested that E. biesmeijeri could also be consistent with the hypothesis that global climates, particularly cooling and drying events, were somehow related to the loss of corbiculate diversity (Engel 2001, 2002; Engel et al. 2013a), and that this was perhaps a global phenomenon impacting similar bee lineages in the New World (Dehon et al. 2014). It is noticeable that extant bumble bees appear especially sensitive to hyperthermal crises (Kerr et al. 2015; Rasmont et al. 2015). These climatic events resulted in significantly floral turnovers and these florist changes certainly could have influenced ancient lineages of bees (Collinson 1992). Those events of successive changes in temperature might have played a role in the appearance or extinction of species studied herein.

\section{Acknowledgements}

The first author is a grant holder of the funds of the University of Mons. For access to pertinent collections we are grateful to the curators and collection managers of the following museums: P.D. Perkins, Museum of Comparative Zoology (Cambridge, 
MA, USA); J.G. Rozen, Jr. and C. Smith, American Museum of Natural History (New York, NY, USA); L. Packer, York University (Toronto, Canada); D. Notton, The Natural History Museum (London, UK); F. Bakker, Naturalis Biodiversity Center (Leiden, The Netherlands); J. Bortels, University of Liège (Gembloux, Belgium); E. De Coninck, Royal Museum of Central Africa (Tervuren, Belgium); W. Dekoninck, Royal Belgian Institute of Natural Sciences (Brussels, Belgium); S. Schmidt, Zoologische Staatssammlung München (Munich, Germany); F. Gusenleitner, Oberösterreichisches Landesmuseum (Linz, Austria); C. Praz, University of Neuchâtel (Neuchâtel, Switzerland); J. Litman, Muséum d'Histoire Naturelle de Neuchâtel (Neuchâtel, Switzerland). For additional assistance in the collections of the University of Kansas Natural History Museum (Lawrence, KS, USA) we are thankful to Z.H. Falin and J.C. Thomas. For providing us pictures of B. beskonakensis and Paraelectrobombus patriciae we are grateful to Gaëlle Doitteau (MNHN, Paris, France), photographs of $B$. vetustus were graciously provided by Prof. Alexandr P. Rasnitsyn (Russian Academy of Sciences, Moscow, Russia), while images of $B$. pristinus were provided courtesy of Dr Irene Zorn and Monika Brüggemann-Ledolter (Geologische Bundesanstalt, Vienna, Austria). This research was supported by the Belgian Science Policy (project BR/132/ A1/BELBEES). Lastly, we thank C. Praz and an anonymous referee for reviewing the paper. This is a contribution of the Division of Entomology, University of Kansas Natural History Museum.

\section{References}

Adams DC, Otárola-Castillo E (2013) Geomorph: An R package for the collection and analysis of geometric morphometric shape data. Methods in Ecology and Evolution 4: 393-399. https://doi.org/10.1111/2041-210X.12035

Akhmetjev MA (1973) Sikhote-Alin Miocene flora (Botchi River). Transactions of the Geological Institute of the Academy of Sciences of the USSR 247: 1-124.

Ansorge J, Kohring R (1995) Insekten aus dem Randecker Maar. Fossilien 2:80-90.

Antropov AV, Belokobylskij SA, Compton SG, Dlussky GM, Khalaim AI, Kolyada VA, Kozlov MA, Perfilieva KS, Rasnitsyn AP (2014) The wasps, bees and ants (Insecta: Vespida = Hymenoptera) from the Insect Limestone (Late Eocene) of the Isle of Wight, UK. Earth and Environmental Science Transactions of the Royal Society of Edinburgh 104: 335-446. https://doi.org/10.1017/S1755691014000103

Arillo A (2001) Presencia de la familia Pompilidae (Insecta, Hymenoptera) en el Mioceno superior de la Cuenca de la Cerdaña (Lleida, NE de España). Coloquios de Paleontología 52: 79-83.

Armbruster L (1938) Versteinerte Honigbienen aus dem obermiocänen Randecker Maar. Archiv für Bienenkunde 19: 1-48.

Aytekin AM, Terzo M, Rasmont P, Cagatay N (2007) Landmark based geometric morphometric analysis of wing shape in Sibiricobombus Vogt (Hymenoptera: Apidae: Bombus Latreille). Annales de la Société Entomologique de France 43: 95-102. https://doi.org/10.10 80/00379271.2007.10697499 
Bachmayer F, Symeonidis N, Theodoropoulos D (1971) Einige Insektenreste as den Jungtertiären Süsswasserablagerungen von Kumi (Insel Euboea, Griechenland). Annales Géologiques des Pays Helléniques 23: 165-174.

Barkan, NP, Aytekin AM (2013) Systematical studies on the species of the subgenus Bombus (Thoracobombus) (Hymenoptera: Apidae, Bombus Latreille) in Turkey. Zootaxa 3737: 167-183. https://doi.org/10.11646/zootaxa.3737.2.5

Berry EW (1929) A revision of the flora of the Latah Formation. United States Geological Surveys Professional Paper 154: 225-265. https://doi.org/10.3133/pp154H

Bookstein FL (1991) Morphometric tools for landmark data: geometry and biology. Cambridge University Press, Cambridge, 435 pp. https://doi.org/10.1017/CBO9780511573064

Bossert S, Murray EA, Almeida EAB, Brady SG, Blaimer BB, Danforth BN (2019) Combining transcriptomes and ultraconserved elements to illuminate the phylogeny of Apidae. Molecular Phylogenetics and Evolution 130: 121-131. https://doi.org/10.1016/j. ympev.2018.10.012

Boyle B, Meyer HW, Enquist B, Salas S (2008) Higher taxa as paleoecological and paleoclimatic indicators: A search for the modern analog of the Florissant fossil flora. In: Meyer HW, Smith DM (Eds) Paleontology of the Upper Eocene Florissant Formation, Colorado, Geological Society of America Special Paper, 435 pp. https://doi.org/10.1130/2008.2435(03)

Brasero N, Martinet B, Lecocq T, Lhomme P, Biella P, Valterová I, Urbanová K, Cronalba M, Hines H, Rasmont P (2018) The cephalic labial gland secretions of two socially parasitic bumblebees Bombus hyperboreus (Alpinobombus) and Bombus inexspectatus (Thoracobombus) question their inquiline strategy. Insect Science 25: 75-86. https://doi.org/10.1111/17447917.12408

Bůžek Č, Holý F, Kvaček Z (1996) Early Miocene flora of the Cypris Shale (western Bohemia). Acta Musei Nationalis Pragae, Series B, Historia Naturalis 52: 1-72.

Cameron SA, Hines HM, Williams PH (2007) A comprehensive phylogeny of the bumblebees (Bombus). Biological Journal of the Linnean Society 91: 161-188. https://doi. org/10.1111/j.1095-8312.2007.00784.x

Cardinal S, Packer L (2007) Phylogenetic analysis of the corbiculate Apinae based on morphology of the sting apparatus (Hymenoptera: Apidae). Cladistics 23: 99-118. https://doi. org/10.1111/j.1096-0031.2006.00137.x

Claude J (2008) Morphometrics with R. Springer, New York, New York, USA, 317 pp.

Cockerell TDA (1906) Fossil Hymenoptera from Florissant, Colorado. Bulletin of the Museum of Comparative Zoology 50: 33-58. https://doi.org/10.2307/2478887

Cockerell TDA (1908) Descriptions and records of bees - XX. Annals and Magazine of Natural History 8: 323-334. https://doi.org/10.1080/00222930808692489

Cockerell TDA (1931) II Hymenoptera and Hemiptera. Insects from the Miocene (Latah) of Washington. Annals of the Entomological Society of America 24: 307-322. https://doi. org/10.1093/aesa/24.2.309

Collinson ME (1992) Vegetational and floristic changes around the Eocene/Oligocene boundary in western and central Europe. In: Prothero DR, Berggren WA (Eds) Eocene-Oligocene climatic and biotic evolution. Princeton University Press, Princeton, NJ, 437-450. https:// doi.org/10.1515/9781400862924.437 
Dehon M, Michez D, Nel A, Engel MS, De Meulemeester T (2014) Wing shape of four new bee fossils (Hymenoptera: Anthophila) provides insights to bee evolution. PLoS ONE 9(10): e108865. https://doi.org/10.1371/journal.pone.0108865

Dehon M, Perrard A, Engel MS, Nel A, Michez D (2017) Antiquity of cleptoparasitism among bees revealed by morphometric and phylogenetic analysis of a Paleocene fossil nomadine (Hymenoptera: Apidae). Systematic Entomology 42(3): 543-554. https://doi. org/10.1111/syen.12230

De Meulemeester T, Michez D, Aytekin AM, Danforth BN (2012) Taxonomic affinity of halictid bee fossils (Hymenoptera: Anthophila) based on geometric morphometrics analyses of wing shape. Journal of Systematic Palaeontology 10(4): 755-764. https://doi.org/10.1 080/14772019.2011.628701

Derkey RE, Hamilton MM, Stradling DF (2003) Geologic Map of the Nine Mile Falls 7.5-minute Quadrangle, Spokane and Stevens Counties, Washington. Washington Division of Geology and Earth Resources Open File Report 2003-8.

Dewulf A, De Meulemeester T, Dehon M, Engel MS, Michez D (2014) A new interpretation of the bee fossil Melitta willardi Cockerell (Hymenoptera, Melittidae) based on geometric morphometrics of the wing. ZooKeys 389: 35-48. https://doi.org/10.3897/zookeys.389.7076

Diéguez C, Nieves-Aldrey J, Barrón E (1996) Fossil galls (zoocecids) from the Upper Miocene of La Cerdaña (Lérida, Spain). Review of Palaeobotany Palynology 94: 329-343. https:// doi.org/10.1016/S0034-6667(96)00004-8

Engel MS (2000) A new interpretation of the oldest fossil bee (Hymenoptera: Apidae). American Museum Novitates 3296: 1-11. https://doi.org/10.1206/0003-0082(2000)3296\%3C000 1:ANIOTO\%3E2.0.CO;2

Engel MS (2001) A monograph of the Baltic amber bees and evolution of the Apoidea (Hymenoptera). Bulletin of the American Museum of Natural History 259: 1-192. https://doi. org/10.1206/0003-0090(2001)259<0001:AMOTBA>2.0.CO;2

Engel MS (2004) Notes on a megachiline bee (Hymenoptera: Megachilidae) from the Miocene of Idaho. Transactions of the Kansas Academy of Sciences 107: 97-100. https://doi. org/10.1660/0022-8443(2004)107[0097:NOAMBH]2.0.CO;2

Engel MS (2014) An orchid bee of the genus Eulaema in Early Miocene Mexican amber (Hymenoptera: Apidae). Novitates Paleoentomologicae 7: 1-15. https://doi.org/10.17161/ np.v0i7.4726

Engel MS (2019a) Die Entwicklungsgeschichte unserer Bienen. Teil I. Lëtzebuerger BeienZeitung 130(6): 198-204.

Engel MS (2019b) Die Entwicklungsgeschichte unserer Bienen. Teil II. Lëtzebuerger BeienZeitung 130(8): 266-273.

Engel MS, Breitkreuz LCV (2013) A male of the bee genus Agapostemon in Dominican amber (Hymenoptera: Halictidae). Journal of Melittology 16: 1-9. https://doi.org/10.17161/ jom.v0i16.4572

Engel MS, Michener CD (2013a) A minute stingless bee in Eocene Fushan [sic] amber from northeastern China (Hymenoptera: Apidae). Journal of Melittology 14: 1-10. https://doi. org/10.17161/jom.v0i14.4560 
Engel MS, Michener CD (2013b) Geological history of the stingless bees (Apidae: Meliponini). In: Vit P, Roubik DW (Eds) Stingless Bees Process Honey and Pollen in Cerumen Pots, 1-7. Facultad de Farmacia y Bioanálisis, Universidad de Los Andes, Mérida, Venezuela, 170 pp. Engel MS, Rasmussen C (in press) Corbiculate bees. In: Starr CK (Ed.) Encyclopedia of Social Insects. Springer, Berlin.

Engel MS, Grimaldi DA, Gonzalez VH, Hinojosa-Díaz IA, Michener CD (2012) An exomalopsine bee in Early Miocene amber from the Dominican Republic (Hymenoptera: Apidae). American Museum Novitates 3758: 1-16. https://doi.org/10.1206/3758.2

Engel MS, Ortega-Blanco J, Nascimbene PC, Singh H (2013) The bees of Early Eocene Cambay amber (Hymenoptera: Apidae). Journal of Melittology 25: 1-12. https://doi. org/10.17161/jom.v0i25.4659

Engel MS, Breitkreuz LCV, Ohl M (2014) The first male of the extinct bee tribe Melikertini (Hymenoptera: Apidae). Journal of Melittology 30: 1-18. https://doi.org/10.17161/jom. v0i30.4698

Engel MS, Wang B, Alqarni AS, Jia L-B, Su T, Zhou Z-K, Wappler T (2018) A primitive honey bee from the middle Miocene deposits of southeastern Yunnan, China (Hymenoptera, Apidae). ZooKeys 775: 117-129. https://doi.org/10.3897/zookeys.775.24909

Epis RC, Chapin CE (1974) Stratigraphic nomenclature of the Thirty-nine Mile volcanic field, central Colorado. U.S. Geological Survey Bulletin, Washington 1395(c): 1-23.

Evanoff E, McIntosh WC, Murphey PC (2001) Stratigraphic summary and ${ }^{40} \mathrm{Ar} /{ }^{39} \mathrm{Ar}$ geochronology of the Florissant Formation, Colorado. Fossil Flora and Stratigraphy of the Florissant Formation, Colorado. Proceedings of the Denver Museum of Nature \& Science Series 4: 1-16.

Francoy TM, Silva RAO, Nunes-Silva P, Menezes C, Imperatriz-Fonseca VL (2009) Gender identification of five genera of stingless bees (Apidae, Meliponini) based on wing morphology. Genetics and molecular research 8: 207-214. https://doi.org/10.4238/vol8-1gmr557

Francoy TM, De Faria Franco F, Roubik DW (2012) Integrated landmark and outline-based morphometric methods efficiently distinguish species of Euglossa (Hymenoptera, Apidae, Euglossini). Apidologie 43: 609-617. https://doi.org/10.1007/s13592-012-0132-2

Gérard M, Michez D, Fournier D, Maebe K, Smagghe G, Biesmeijer JC, De Meulemeester T (2015) Discrimination of haploid and diploid males of Bombus terrestris (Hymenoptera; Apidae) based on wing shape. Apidologie 46: 644-653. https://doi.org/10.1007/s13592015-0352-3

Gérard M, Michez D, Debat V, Fullgrabe, L, Meeus I, Piot N, Sculfort O, Vastrade M, Smagghe G, Vanderplanck M (2018) Stressful conditions reveal decrease in size, modification of shape but relatively stable asymmetry in bumblebee wings. Scientific Reports 8: 15169 . https://doi.org/10.1038/s41598-018-33429-4

Goulson D (2010) Bumblebees: Behaviour, Ecology, and Conservation. Oxford University Press, Oxford, $317 \mathrm{pp}$.

Gray J, Kittleman R (1967) Geochronometry of the Columbia River Basalt and associated floras of eastern Washington and western Idaho. American Journal of Science 26: 251-291. https://doi.org/10.2475/ajs.265.4.257

Gregor HJ (1986) Zur Flora des Randecker Maares (Miozän, Baden-Württemberg). Stuttgarter Beiträge zur Naturkunde, Serie B (Geologie und Paläontologie) 122: 1-24. 
Hansen J, Sato M, Russell G, Kharecha P (2013) Climate sensitivity, sea level and atmospheric carbon dioxide Climate sensitivity, sea level and atmospheric carbon dioxide. Philosophical Transactions of the Royal Society of London A 371: 20120294. https://doi.org/10.1098/ rsta.2012.0294

Heinrich B (1979) Bumblebee Economics. Harvard University Press, Cambridge, Massachusetts, 288 pp.

Heizmann EPJ (1983) Die Gattung Cainotherium (Cainotheriidae) im Orleanium und Astracium Süddeutschlands. Eclogae Geologicae Helvetiae 76: 781-825.

Hines HM (2008) Historical biogeography, divergence times, and diversification patterns of bumblebees (Hymenoptera: Apidae: Bombus). Systematic Biology 57: 58-75. https://doi. org/10.1080/10635150801898912

Hines HM, Cameron SA (2010) The phylogenetic position of the bumblebee inquiline Bombus inexspectatus and implications for the evolution of social parasitism. Insectes Sociaux 57: 379-383. https://doi.org/10.1007/s00040-010-0094-1

Huberty CJ, Olejnik S (2006) Applied MANOVA and discriminant analysis. Second Edition, New Jersey, 488 pp. https://doi.org/10.1002/047178947X

Ito M (1985) Supraspecific classification of bumblebees based on the characters of male genitalia. Contributions from the Institute of Low Temperature Science, Series B 20: 1-143.

Jiménez-Moreno G, Fauquette S, Suc J-P (2010) Miocene to Pliocene vegetation reconstruction and climate estimates in the Iberian Peninsula from pollen data. Review of Palaeobotany and Palynology 162: 403-415. https://doi.org/10.1016/j.revpalbo.2009.08.001

Kawakita A, Sota T, Ito M, Asher JS, Tanaka H, Kato M, Roubik DW (2004) Phylogeny, historical biogeography, and character evolution in bumble bees (Bombus: Apidae) based on simultaneous analysis of three nuclear gene sequences. Molecular Phylogenetics and Evolution 31: 799-804. https://doi.org/10.1016/j.ympev.2003.12.003

Kennedy WJ, Reyment RA, Macleod N, Kriege J (2009) Species discrimination in the lower cretaceous (Albian) ammonite genus. Palaeontographica, Abteilung A: Palaozoologie Stratigraphie 290: 1-63. https://doi.org/10.1127/pala/290/2009/1

Kerr JT, Pindar A, Galpern P, Packer L, Potts SG, Roberts SM, Rasmont R, Schweiger O, Colla SR, Richardson LL, Wagner DL, Gall LF, Sikes DS, Pantoja A (2015) Climate change impacts on bumblebees converge across continents. Science 349: 177-180. https://doi. org/10.1126/science.aaa7031

Kirkham V, Melville M (1929) The Latah Formation. The Journal of Geology 37: 483-504. https://doi.org/10.1086/623639

Knor S, Prokop J, Kăvcek Z, Janovský Z, Wappler T (2012) Plant-arthropod associations from the Early Miocene of the Most Basin in North Bohemia - Palaeoecological and palaeoclimatological implications. Palaeogeography, Palaeoclimatology, Palaeoecology 321-322: 102-112. https://doi.org/10.1016/j.palaeo.2012.01.023

Köppen W, Geiger R (1928) Klimakarte der Erde [Wall Map 150 cm X 200 cm]. Verlag Justus Perthes, Gotha.

Kottek M, Grieser J, Beck C, Rudolf B, Rubel F (2006) World map of the Köppen-Geiger climate classification updated. Meteorologische Zeitschrift 15: 259-263. https://doi. org/10.1127/0941-2948/2006/0130 
Kotthoff U (2005) Ü ber einige Hymenoptera (Insecta) aus dem Unter-Miozän des Randecker Maars (Schwäbische Alb, Südwestdeutschland). Stuttgarter Beiträge zur Naturkunde, Serie B (Geologie und Paläontologie) 355: 1-25.

Kotthoff U, Schmid U (2005) A new fossil hoverfly (Insecta, Diptera: Syrphidae) from the Randeck Maar (Early Miocene, southwest Germany). Palaeontology 48: 1091-1096. https://doi.org/10.1111/j.1475-4983.2005.00500.x

Kotthoff U, Wappler T, Engel MS (2011) Miocene honey bees from the Randeck Maar of southwestern Germany (Hymenoptera, Apidae). ZooKeys 96: 11-37. https://doi.org/10.3897/ zookeys.96.752

Krautter M, Schweigert G (1991) Bemerkungen zur Sedimentation, Flora und dem Paläoklima des Randecker Maars (Unter-/Mittel-Miozän, Schwäbische Alb). Neues Jahrbuch für Geologie und Paläontologie, Monatshefte 1991: 505-514.

Kvaček Z (1998) Bílina: a window on Early Miocene marshland environments. Review of Palaeobotany and Palynology 101: 111-113. https://doi.org/10.1016/S0034-6667(97)00072-9

Kvaček Z, Böhme M, Dvořák Z, Konzalová M, Mach K, Prokop J, Rajchl M (2004) Early Miocene freshwater and swamp ecosystems of the Most Basin (northern Bohemia) with particular reference to the Bílina mine section. Journal of the Czech Geological Society 49: 1-40.

Krzemiński W, Prokop J (2011) Ptychoptera deleta Novák, 1877 from the Early Miocene of the Czech Republic: redescription of the first fossil attributed to Ptychopteridae (Diptera). ZooKeys 130: 299-305. https://doi.org/10.3897/zookeys.130.1401

Lewis S (1969) Fossil insects of the Latah Formation (Miocene) of Eastern Washington and Northern Idaho. Northwest Science 43: 99-115.

Lutz H, Neuffer FO, Harms F-J, Schaal S, Micklich N, Gruber G, Schweigert G, Loren V (2000) Tertïare Maare als Fossillagerstätten: Eckfeld, Messel, Randeck, Höwenegg, Öhning. Mainzer naturwissenschaftliches Archiv, Beiheft 24: 125-160.

Michener CD (1990) Classification of the Apidae (Hymenoptera). University of Kansas Science Bulletin 54: 75-163.

Michener CD (2007) The bees of the world, second edition. The Johns Hopkins University Press, Baltimore, 953 pp. [20 pls.]

Michener CD, Grimaldi DA (1988) A Trigona from Late Cretaceous amber of New Jersey (Hymenoptera: Apidae: Meliponinae). American Museum Novitates 2917: 1-10.

Michez D, Patiny S, Danforth BN (2009a) Phylogeny of the bee family Melittidae (Hymenoptera: Anthophila) based on combined molecular and morphological data. Systematic Entomology 34: 574-597. https://doi.org/10.1111/j.1365-3113.2009.00479.x

Michez D, De Meulemeester T, Rasmont P, Nel A, Patiny S (2009b) New fossil evidence of the early diversification of bees: Paleohabropoda oudardi from the French Paleocene (Hymenoptera, Apidae, Anthophorini). Zoologica Scripta 38: 171-181. https://doi.org/10.1111/ j.1463-6409.2008.00362.x

Michez D, Vanderplanck M, Engel MS (2012) Fossil bees and their plant associates. In: Patiny $S$ (Ed.) Evolution of Plant-Pollinator Relationships. Cambridge University Press, Cambridge, 103-164. https://doi.org/10.1017/CBO9781139014113.006

Milliron HE (1961) Revised classification of the bumblebees - A synopsis. Journal of the Kansas Entomological Society 34: 49-61. 
Milliron HE (1971) A monograph of the western hemisphere bumblebees (Hymenoptera: Apidae; Bombinae). I. The genera Bombus and Megabombus subgenus Bombias. Memoirs of the Entomological Society of Canada 82: 1-80. https://doi.org/10.4039/entm10382fv

Milliron HE (1973a) A monograph of the western hemisphere bumblebees (Hymenoptera: Apidae; Bombinae). II. The genus Megabombus subgenus Megabombus. Memoirs of the Entomological Society of Canada 89: 81-237. https://doi.org/10.4039/entm10589fv

Milliron HE (1973b) A monograph of the western hemisphere bumblebees (Hymenoptera: Apidae; Bombinae). III. The genera Pyrobombus subgenus Cullumanobombus. Memoirs of the Entomological Society of Canada 91: 238-333.

Mlíkovský J (1996) Tertiary avian localities of the Czech Republic. Acta Universitatis Carolinae Geologica 39: 551-557.

Moure JS, Camargo JMF (1978) A fossil stingless bee from copal (Hymenoptera: Apidae). Journal of the Kansas Entomological Society 51(4): 560-566.

Mustoe GE (2008) Mineralogy and geochemistry of late Eocene silicified wood from Florissant Fossil Beds National Monument, Colorado. In: Meyer HW, Smith DM (Eds) Paleontology of the Upper Eocene Florissant Formation, Colorado: Geological Society of America Special Paper 435: 127-140. https://doi.org/10.1130/2008.2435(09)

Nel A, Petrulevičius JF (2003) New Palaeogene bees from Europe and Asia. Alcheringa 27: 227-293. https://doi.org/10.1080/03115510308619108

Nel A, Martínez-Delclòs X, Arillo A, Peñalver E (1999) The fossil Apis Linnaeus, 1758 (Hymenoptera, Apidae). Palaeontology 42: 243-285. https://doi.org/10.1111/1475-4983.00073

Novák O (1878) Fauna der Cyprisschiefer des Egerer Tertiärbeckens. Sitzungsberichte der Mathematisch-Naturwissenschaftlichen Classe der Kaiserlichen Akademie der Wissenschaften 76: 71-96.

Obrecht E, Scholl A (1981) Enzymelektrophoretische Untersuchungen zur Analyse der Verwandtschaftsgrade zwischen Hummel- und Schmarotzerhummelarten (Apidae, Bombini). Apidologie 12: 257-268. https://doi.org/10.1051/apido:19810303

Owen RE (2012) Applications of morphometrics to the Hymenoptera, particularly bumblebees (Bombus, Apidae). In: Wahl C (Ed.) Morphometrics. IntechOpen, London, 1-30. https://doi.org/10.5772/34745

Paichelier J-C, De Broin F, Gaudant J, Mourer-Chauvire C, Rage JC, Vergnaud-Grazzini C (1978) Le bassin lacustre de Bes-Konak (Anatolie, Turquie). Géologie et introduction à la paléontologie des vertébrés. Geobios 11: 43-65. https://doi.org/10.1016/S00166995(78)80018-7

Pamilo P, Pekkarinen A, Varvio S-L (1987) Clustering of bumblebee subgenera based on interspecific genetic relationships (Hymenoptera, Apidae: Bombus and Psithyrus). Annales Zoologici Fennici 24: 19-27.

Pekkarinen A (1979) Morphometric, colour and enzyme variation in bumblebees (Hymenoptera, Apidae, Bombus) in Fennoscandia and Denmark. ACTA Zoologica Fennica 158: 1-60.

Pekkarinen A, Varvio-Aho SL, Pamilo P (1979) Evolutionary relationships in northern European Bombus and Psithyrus species (Hymenoptera: Apidae) studied on the basis of allozymes. Annales Entomologici Fennici 45: 77-80. 
Peñalver-Molla E, Martínez-Delclòs X, Arillo A (1999) Yacimientos con insectos fósiles en España. Revista Espańola de Palaeontologia 14: 231-245.

Perrard A, Baylac M, Carpenter JM, Villemant C (2014) Evolution of wing shape in hornets: why is the wing venation efficient for species identification? Journal of Evolutionary Biology 27: 2665-2675. https://doi.org/10.1111/jeb.12523

Perrard A, Lopez-Osorio F, Carpenter JM (2016) Phylogeny, landmark analysis and the use of wing venation to study the evolution of social wasps (Hymenoptera: Vespidae: Vespinae). Cladistics 32: 406-425. https://doi.org/10.1111/cla.12138

Petit D, Picaud F, Elghadraoui L (2006) Géométrie morphologique des ailes des Acrididae (Orthoptera : Caelifera) : sexe, stridulation, caractère. Annales de la société entomologique de France 42: 63-73. https://doi.org/10.1080/00379271.2006.10697450

Plowright RC, Laverty TM (1987) Bumblebees and crop pollination in Ontario. Proceedings of the Entomological Society of Ontario 118: 155-160.

Pouvreau A (1984) Biologie et écologie des bourdons. In: Pesson P, Louveaux J (Eds) Pollinisation et Production Végétales. INRA, Paris, 595-630.

Pretorius E (2005) Using geometric morphometrics to investigate wing dimorphism in males and females of Hymenoptera - a case study based on the genus Tachysphex Kohl (Hymenoptera: Sphecidae: Larrinae). Australian Journal of Entomology 44: 113-121. https://doi. org/10.1111/j.1440-6055.2005.00464.x

Prokop J, Nel A (2000) Merlax bohemicus gen. n., sp. n., a new fossil dragonfly from the Lower Miocene of northern Bohemia (Odonata: Aeshnidae). European Journal of Entomology 97: 427-431. https://doi.org/10.14411/eje.2000.065

Prokop J, Fleck G, Nel A (2003) New dragonflies from the Lower Miocene (Ottnangian/Karpatian) of the Cypris Shale in western Bohemia (Odonata: Libellulidae). Neues Jahrbuch für Geologie und Paläontologie, Monatshefte 2003: 561-576.

Prokop J, Dehon M, Michez D, Engel MS (2017) An Early Miocene bumble bee from northern Bohemia (Hymenoptera, Apidae). ZooKeys 710: 43-63. https://doi.org/10.3897/ zookeys.710.14714

R Development Core Team (2013) A language and environment for statistical computing, version 3.0.2, ISBN 3-900051-07-0, R Foundation for Statistical Computing. Vienna, Austria.

Rasmont P, Franzen M, Lecocq T, Harpke A, Roberts SPM, Biesmeijer K, Castro L, Cederberg B, Dvorak L, Fitzpatrick U, Gonseth Y, Haubruge E, Mahé G, Manino A, Michez D, Neumayer J, Odegaard F, Paukkunen J, Pawlikowski T, Potts SG, Reemer M, Settele J, Straka J, Schweiger O (2015) Climatic Risk and Distribution Atlas of European Bumblebees. Pensoft Publishers, Sofia, 246 pp. https://doi.org/10.3897/biorisk.10.4749

Rasnitsyn AP, Michener CD (1991) Miocene fossil bumblebee from the Soviet far east with comments on the chronology and distribution of fossil bees (Hymenoptera: Apidae). Annals of Entomological Society of America 84: 583-589. https://doi.org/10.1093/aesa/84.6.583

Robinson JD (1991) Stratigraphy and sedimentology of the Latah Formation, Spokane County, Washington. Master of Science thesis, Washington, Eastern Washington University.

Rohlf FJ (1999) Shape statistics: Procrustes superimpositions and tangent spaces. Journal of classification 16: 197-223. https://doi.org/10.1007/s003579900054

Rohlf FJ (2013a) tpsUTIL Version 1.56. Department of Ecology and Evolution, State University of New York at Stony Brook, New York. 
Rohlf FJ (2013b) tpsDIG Version 2.17. Department of Ecology and Evolution, State University of New York at Stony Brook, New York.

Rohlf FJ (2013c) tpsSMALL Version 1.25. Department of Ecology and Evolution, State University of New York at Stony Brook, New York.

Rohlf FJ, Slice D (1990) Extensions of the Procrustes method for the optimal superimposition of landmarks. Systematic Zoology 39: 40-59. https://doi.org/10.2307/2992207

Rojík P (2004) New stratigraphic subdivision of the Tertiary in the Sokolov Basin. Journal of the Czech Geological Society 49: 173-185.

Röseler P-F (1973) Die Anzahl der Spermien im Receptaculum seminis von Hummelköniginnen (Hym., Apoidea, Bombinae). Apidologie 4: 267-274. https://doi.org/10.1051/apido: 19730303

Royer DL (2006) $\mathrm{CO}_{2}$-forced climate thresholds during the Phanerozoic. Geochimica et Cosmochimica Acta 70(23 SPEC. ISS.): 5665-5675. https://doi.org/10.1016/j.gca.2005.11.031

Sadeghi S, Adriaens D, Dumont HJ (2009) Geometric morphometric analysis of wing shape variation in ten European populations of Calopteryx splendens (Haris, 1782) (Zygoptera: Odonata). Odonatologica 38(4): 343-360.

Schawaller W (1986) Fossile Käfer aus miozänene Sedimenten des Randecker Maars in Südwestdeutschland (Insecta: Coleoptera). Stuttgarter Beiträge zur Naturkunde, Serie B (Geologie und Paläontologie) 126: 1-9.

Schweigert G (1998) Das Randecker Maar - ein fossiler Kratersee am Albtrauf. Stuttgarter Beiträge zur Naturkunde, Serie C (Wissen für Alle) 43: 1-70.

Skorikov AS (1923) Palaearctic bumblebees. Part I. General biology (including zoogeography). Izvestiya Severnoi oblastnoi stantsii zashchity rastenii ot vreditelei 4(1922): 1-160.

Swisher CC, Prothero DR (1990) Single-crystal ${ }^{40} \mathrm{Ar} /{ }^{39} \mathrm{Ar}$ dating of the Eocene-Oligocene transition in North America. Science 249: 760-762. https://doi.org/10.1126/science.249.4970.760

Tkalců B (1972) Arguments contre l'interprétation traditionnelle de la phylogénie des abeilles. Bulletin de la Société Entomologique de Mulhouse 1972: 17-28.

Unger F (1867) Die Fossile Flora Von Kumi Auf Der Insel Euboea. Denkschriften der Kaiserlichen Akademie der Wissenschaften in Wien, Mathematisch-Naturwissenschaftlichen Classe 27: 27-90.

Van Cann J, Virgilio M, Jordaens K, De Meyer M (2015) Wing morphometrics as a possible tool for the diagnosis of the Ceratitis fasciventris, C. anonae, C. rosa complex (Diptera, Tephritidae). ZooKeys 540: 489-506. https://doi.org/10.3897/zookeys.540.9724

Veatch SW, Meyer HW (2008) History of paleontology at the Florissant fossil beds, Colorado. In: Meyer HW, Smith DM (Eds) Paleontology of the Upper Eocene Florissant Formation, Colorado. Geological Society of America Special Paper, 1-18. https://doi. org/10.1130/2008.2435(01)

Velthuis HHW, Doorn A (2006) A century of advances in bumblebee domestication and the economic and environmental aspects of its commercialization for pollination. Apidologie 37: 421-451. https://doi.org/10.1051/apido:2006019

Vogt O (1911) Studien über das Artproblem. 2. Mitteilung. Über das Variieren der Hummeln. 2. Teil (Schluss). Schriften der berlinischen Gesellschaft Naturforschender, Freunde, Berlin 1911: 31-74. 
Walker JCG, Hays PB, Kasting JFA (1981) A negative feedback mechanism for the longterm stabilization of Earth's surface-temperature. Journal of Geophysical Research 86: 9776 9782. https://doi.org/10.1029/JC086iC10p09776

Wappler T, De Meulemeester T, Aytekin AM, Michez D, Engel MS (2012) Geometric morphometric analysis of a new Miocene bumble bee from the Randeck Maar of southwestern Germany (Hymenoptera: Apidae). Systematic Entomology 37(4): 784-792. https://doi. org/10.1666/0022-3360(2003)077<0908:TMEBFO>2.0.CO;2

Wille A, Chandler L (1964) A new stingless bee from the Tertiary amber of the Dominican Republic (Hymenoptera; Meliponini). Revista de Biología Tropical 12: 187-195.

Williams PH (1985) A preliminary cladistic investigation of relationships among the bumblebees (Hymenoptera, Apidae). Systematic Entomology 10: 239-255. https://doi. org/10.1111/j.1365-3113.1985.tb00529.x

Williams PH (1998) An annotated checklist of bumblebees with an analysis of patterns of description (Hymenoptera: Apidae, Bombini). Bulletin of The Natural History Museum (Entomology) 67(1): 79-152.

Williams PH (2007) The distribution of bumblebee colour patterns world-wide: possible significance for thermoregulation, crypsis and warming mimicry. Biological Journal of the Linnean Society 92: 97-118. https://doi.org/10.1111/j.1095-8312.2007.00878.x

Williams PH, Cameron SA, Hines HM, Cederberg B, Rasmont P (2008) A simplified subgeneric classification of the bumblebees (genus Bombus). Apidologie 39: 46-74. https://doi. org/10.1051/apido:2007052

Williams PH, Thorp RW, Richardson LL, Colla SR (2014) Bumblebees of North America. An identification guide. Princeton University Press, Princeton, New Jersey, 208 pp.

Williams PH, Huang J, Rasmont P, An J (2016) Early-diverging bumblebees from across the roof of the world: the high-mountain subgenus Mendacibombus revised from species' gene coalescence and morphology (Hymenoptera, Apidae). Zootaxa 4204(1): 1-72. https://doi. org/10.11646/zootaxa.4204.1.1

Williams PH, Lobo JM, Meseguer AS (2018) Bumblebees take the high road: climatically integrative biogeography shows that escape from Tibet, not Tibetan uplift, is associated with divergences of present-day Mendacibombus. Ecography 41: 461-477. https://doi. org/10.1111/ecog.03074

Williams PH, Berezin MV, Cannings SG, Cederberg B, Odegaard F, Rasmussen C, Richardson LL, Rykken J, Sheffield CS, Thanoosing C, Byvaltsev AM (2019) The arctic and alpine bumblebees of the subgenus Alpinobombus revised from integrative assessment of species gene coalescence and morphology (Hymenoptera, Apidae, Bombus). Zootaxa 4625: 1-68. https://doi.org/10.11646/zootaxa.4625.1.1

Yang J, Wang Y-F, Spicer RA, Mosbrugger V, Li C-S, Sun Q-G (2007) Climatic reconstruction at the Miocene Shanwang Basin, China, using leaf margin analysis, CLAMP, coexistence approach, and overlapping distribution analysis. American Journal of Botany 94: 599-608. https://doi.org/10.3732/ajb.94.4.599

Zachos J, Pagani M, Sloan L, Thomas E, Billups K (2001) Trends, rhythms, and aberrations in global climate 65 Ma to present. Science 292 (5517): 686-693. https://doi.org/10.1126/ science. 1059412 
Zachos JC, Dickens GR, Zeebe RE (2008) An early Cenozoic perspective on greenhouse warming and carbon-cycle dynamics. Nature 451: 279-283. https://doi.org/10.1038/nature06588

Zeuner FE, Manning FJ (1976) A monograph on fossil bees (Hymenoptera: Apoidea). Bulletin of the British Museum (Natural History), Geology 27: 149-268.

Zhang JF (1990) New fossil species of Apoidea (Insecta: Hymenoptera). Acta Zootaxonomica Sinica 15: 83-91.

Zhang JF, Sun B, Zhang XY (1994) Miocene Insects and Spiders from Shanwang, Shandong. Science Press, Beijing, 298 pp.

\section{Supplementary material I}

Table S1. First dataset for the geometric morphometric analyses

Authors: Manuel Dehon, Michael S. Engel, Maxence Gérard, A. Murat Aytekin, Guillaume Ghisbain, Paul H. Williams, Pierre Rasmont, Denis Michez

Data type: species data

Explanation note: This sampling includes 988 specimens from 233 species, 141 genera, 53 tribes, 19 subfamilies, and 7 families of Apoidea Anthophila. N1 = number of species. $\mathrm{N} 2$ = number of specimens.

Copyright notice: This dataset is made available under the Open Database License (http://opendatacommons.org/licenses/odbl/1.0/). The Open Database License $(\mathrm{ODbL})$ is a license agreement intended to allow users to freely share, modify, and use this Dataset while maintaining this same freedom for others, provided that the original source and author(s) are credited.

Link: https://doi.org/10.3897/zookeys.891.32056.suppl1

\section{Supplementary material 2}

Table S2. Second dataset for the geometric morphometric analyses

Authors: Manuel Dehon, Michael S. Engel, Maxence Gérard, A. Murat Aytekin, Guillaume Ghisbain, Paul H. Williams, Pierre Rasmont, Denis Michez

Data type: species data

Explanation note: This sampling includes 973 specimens from 252 species, 19 genera, and five tribes of Apidae. $\mathrm{N}=$ number of specimens.

Copyright notice: This dataset is made available under the Open Database License (http://opendatacommons.org/licenses/odbl/1.0/). The Open Database License $(\mathrm{ODbL})$ is a license agreement intended to allow users to freely share, modify, and use this Dataset while maintaining this same freedom for others, provided that the original source and author(s) are credited.

Link: https://doi.org/10.3897/zookeys.891.32056.suppl2 


\section{Supplementary material 3}

Table S3. Specimen assignment in families using the cross-validation procedure in the LDA of forewing shape in first dataset

Authors: Manuel Dehon, Michael S. Engel, Maxence Gérard, A. Murat Aytekin, Guillaume Ghisbain, Paul H. Williams, Pierre Rasmont, Denis Michez

Data type: statistical data

Explanation note: Original groups are along the rows, predicted groups are along the columns. The hit ratio (HR\%) is given for each family.

Copyright notice: This dataset is made available under the Open Database License (http://opendatacommons.org/licenses/odbl/1.0/). The Open Database License $(\mathrm{ODbL})$ is a license agreement intended to allow users to freely share, modify, and use this Dataset while maintaining this same freedom for others, provided that the original source and author(s) are credited.

Link: https://doi.org/10.3897/zookeys.891.32056.suppl3

\section{Supplementary material 4}

Table S4. Specimen assignment in subfamilies using the cross-validation procedure in the LDA of forewing shape in first dataset

Authors: Manuel Dehon, Michael S. Engel, Maxence Gérard, A. Murat Aytekin, Guillaume Ghisbain, Paul H. Williams, Pierre Rasmont, Denis Michez

Data type: statistical data

Explanation note: Original groups are along the rows, predicted groups are along the columns. The hit ratio (HR\%) is given for each subfamily.

Copyright notice: This dataset is made available under the Open Database License (http://opendatacommons.org/licenses/odbl/1.0/). The Open Database License $(\mathrm{ODbL})$ is a license agreement intended to allow users to freely share, modify, and use this Dataset while maintaining this same freedom for others, provided that the original source and author(s) are credited.

Link: https://doi.org/10.3897/zookeys.891.32056.suppl4 


\section{Supplementary material 5}

Table S5. Specimen assignment in tribes using the cross-validation procedure in the LDA of forewing shape in first dataset

Authors: Manuel Dehon, Michael S. Engel, Maxence Gérard, A. Murat Aytekin, Guillaume Ghisbain, Paul H. Williams, Pierre Rasmont, Denis Michez

Data type: statistical data

Explanation note: Original groups are along the rows, predicted groups are along the columns. The hit ratio $(\mathrm{HR} \%)$ is given for each tribe.

Copyright notice: This dataset is made available under the Open Database License (http://opendatacommons.org/licenses/odbl/1.0/). The Open Database License $(\mathrm{ODbL})$ is a license agreement intended to allow users to freely share, modify, and use this Dataset while maintaining this same freedom for others, provided that the original source and author(s) are credited.

Link: https://doi.org/10.3897/zookeys.891.32056.suppl5

\section{Supplementary material 6}

Table S6. Specimen assignment in tribes using the cross-validation procedure in the LDA of forewing shape in the second dataset

Authors: Manuel Dehon, Michael S. Engel, Maxence Gérard, A. Murat Aytekin, Guillaume Ghisbain, Paul H. Williams, Pierre Rasmont, Denis Michez

Data type: statistical data

Explanation note: Original groups are along the rows, predicted groups are along the columns. The hit ratio (HR\%) is given for each tribe.

Copyright notice: This dataset is made available under the Open Database License (http://opendatacommons.org/licenses/odbl/1.0/). The Open Database License $(\mathrm{ODbL})$ is a license agreement intended to allow users to freely share, modify, and use this Dataset while maintaining this same freedom for others, provided that the original source and author(s) are credited.

Link: https://doi.org/10.3897/zookeys.891.32056.suppl6 


\section{Supplementary material 7}

Table S7. Specimen assignment in subgenera using the cross-validation procedure in the LDA of forewing shape in the third dataset

Authors: Manuel Dehon, Michael S. Engel, Maxence Gérard, A. Murat Aytekin, Guillaume Ghisbain, Paul H. Williams, Pierre Rasmont, Denis Michez

Data type: statistical data

Explanation note: Original groups are along the rows, predicted groups are along the columns. The hit ratio (HR\%) is given for each subgenus.

Copyright notice: This dataset is made available under the Open Database License (http://opendatacommons.org/licenses/odbl/1.0/). The Open Database License $(\mathrm{ODbL})$ is a license agreement intended to allow users to freely share, modify, and use this Dataset while maintaining this same freedom for others, provided that the original source and author(s) are credited.

Link: https://doi.org/10.3897/zookeys.891.32056.suppl7

\section{Supplementary material 8}

Table S8. Specimen assignment in subgenera using the cross-validation procedure in the LDA of forewing shape based on male wing shapes

Authors: Manuel Dehon, Michael S. Engel, Maxence Gérard, A. Murat Aytekin, Guillaume Ghisbain, Paul H. Williams, Pierre Rasmont, Denis Michez

Data type: statistical data

Explanation note: Original groups are along the rows, predicted groups are along the columns. The hit ratio (HR\%) is given for each family.

Copyright notice: This dataset is made available under the Open Database License (http://opendatacommons.org/licenses/odbl/1.0/). The Open Database License $(\mathrm{ODbL})$ is a license agreement intended to allow users to freely share, modify, and use this Dataset while maintaining this same freedom for others, provided that the original source and author(s) are credited.

Link: https://doi.org/10.3897/zookeys.891.32056.suppl8 


\section{Supplementary material 9}

Table S9. Mahalanobis distances (MD) between family centroids and the 988 specimens, and the fossil and family centroids in the first dataset

Authors: Manuel Dehon, Michael S. Engel, Maxence Gérard, A. Murat Aytekin, Guillaume Ghisbain, Paul H. Williams, Pierre Rasmont, Denis Michez

Data type: statistical data

Copyright notice: This dataset is made available under the Open Database License (http://opendatacommons.org/licenses/odbl/1.0/). The Open Database License $(\mathrm{ODbL})$ is a license agreement intended to allow users to freely share, modify, and use this Dataset while maintaining this same freedom for others, provided that the original source and author(s) are credited.

Link: https://doi.org/10.3897/zookeys.891.32056.suppl9

\section{Supplementary material 10}

Table S10. Mahalanobis distances (MD) between subfamily centroids and the 988 specimens, and the fossil and subfamily centroids in the first dataset

Authors: Manuel Dehon, Michael S. Engel, Maxence Gérard, A. Murat Aytekin, Guillaume Ghisbain, Paul H. Williams, Pierre Rasmont, Denis Michez

Data type: statistical data

Copyright notice: This dataset is made available under the Open Database License (http://opendatacommons.org/licenses/odbl/1.0/). The Open Database License (ODbL) is a license agreement intended to allow users to freely share, modify, and use this Dataset while maintaining this same freedom for others, provided that the original source and author(s) are credited.

Link: https://doi.org/10.3897/zookeys.891.32056.suppl10

\section{Supplementary material I I}

Table S11. Mahalanobis distances (MD) between tribe centroids and the 988 specimens, and the fossil and tribe centroids in the first dataset

Authors: Manuel Dehon, Michael S. Engel, Maxence Gérard, A. Murat Aytekin, Guillaume Ghisbain, Paul H. Williams, Pierre Rasmont, Denis Michez

Data type: statistical data

Copyright notice: This dataset is made available under the Open Database License (http://opendatacommons.org/licenses/odbl/1.0/). The Open Database License $(\mathrm{ODbL})$ is a license agreement intended to allow users to freely share, modify, and use this Dataset while maintaining this same freedom for others, provided that the original source and author(s) are credited.

Link: https://doi.org/10.3897/zookeys.891.32056.suppl11 


\section{Supplementary material I 2}

Table S12. Mahalanobis distances (MD) between tribe centroids and the 973 specimens, and the fossil and tribe centroids in the second dataset

Authors: Manuel Dehon, Michael S. Engel, Maxence Gérard, A. Murat Aytekin, Guillaume Ghisbain, Paul H. Williams, Pierre Rasmont, Denis Michez

Data type: statistical data

Copyright notice: This dataset is made available under the Open Database License (http://opendatacommons.org/licenses/odbl/1.0/). The Open Database License $(\mathrm{ODbL})$ is a license agreement intended to allow users to freely share, modify, and use this Dataset while maintaining this same freedom for others, provided that the original source and author(s) are credited.

Link: https://doi.org/10.3897/zookeys.891.32056.suppl12

\section{Supplementary material 13}

Table S13. Mahalanobis distances (MD) between subgenus centroids and the 841 specimens, and the fossils and subgenus centroids in the third dataset

Authors: Manuel Dehon, Michael S. Engel, Maxence Gérard, A. Murat Aytekin, Guillaume Ghisbain, Paul H. Williams, Pierre Rasmont, Denis Michez

Data type: statistical data

Copyright notice: This dataset is made available under the Open Database License (http://opendatacommons.org/licenses/odbl/1.0/). The Open Database License (ODbL) is a license agreement intended to allow users to freely share, modify, and use this Dataset while maintaining this same freedom for others, provided that the original source and author(s) are credited.

Link: https://doi.org/10.3897/zookeys.891.32056.suppl13 